\title{
Testing long-term patterns of basin sedimentation by detrital zircon geochronology, Centralian Superbasin, Australia
}

\author{
D. W. Maidment, ${ }^{*} \uparrow, 1$ I. S. Williams* and M. Hand $\ddagger$ \\ *Research School of Earth Sciences, Australian National University, Canberra, ACT, Australia \\ $\dagger$ Geoscience Australia, Canberra, ACT, Australia \\ $\ddagger$ Geology and Geophysics, University of Adelaide, Adelaide, SA, Australia
}

\begin{abstract}
Detrital zircon geochronology of Neoproterozoic to Devonian sedimentary rocks from the Georgina and Amadeus basins has been used to track changes in provenance that reflect the development and inversion of the former Australian Superbasin. Through much of the Neoproterozoic, sediments appear to have been predominantly derived from local sources in the Arunta and Musgrave inliers. Close similarities between the detrital age signatures of late Neoproterozoic sedimentary rocks in the two basins suggests that they were contiguous at this time. A dominant population of $1.2-1.0 \mathrm{Ga}$ zircon in Early Cambrian sediments of the Amadeus Basin reflects the uplift of the Musgrave Inlier during the Petermann Orogeny between 560 and $520 \mathrm{Ma}$, which shed a large volume of detritus northwards into the Amadeus Basin. Early Cambrian sedimentary rocks in the Georgina Basin have a much smaller proportion of 1.2-1.0 Ga detritus, possibly due to the formation of sub-basins along the northern margin of the Amadeus Basin which might have acted as a barrier to sediment transfer. An influx of $0.6-0.5 \mathrm{Ga}$ zircon towards the end of the Cambrian coincides with the transgression of the Larapintine Sea across central Australia, possibly as a result of intracratonic rifting. Detrital zircon age spectra of sedimentary rocks deposited within this epicontinental sea are very similar to those of coeval sedimentary rocks from the Pacific Gondwana margin, implying that sediment was transported into central Australia from the eastern continental margin. The remarkably consistent 'Pacific Gondwana' signature of Cambro-Ordovician sediments in central and eastern Australia reflects a distal source, possibly from east Antarctica or the East African Orogen. The peak of the marine incursion into central Australia in the early to mid Ordovician coincides with granulite-facies metamorphism at mid-crustal depths between the Amadeus and Georgina basins (the Larapinta Event). The presence of the epicontinental sea, the relative lack of a local basement zircon component in Cambro-Ordovician sedimentary rocks and their maturity suggest that metamorphism was not accompanied by mountain building, consistent with an extensional or transtensional setting for this tectonism. Sediments deposited at $\sim 435-405$ and $\sim 365$ Ma during the Alice Springs Orogeny have detrital age signatures similar to those of Cambro-Ordovician sedimentary rocks, reflecting uplift and reworking of the older succession into narrow foreland basins adjacent to the orogen.
\end{abstract}

\section{INTRODUCTION}

The depositional record of sedimentary basins provides valuable information about the effects of local tectonism, complementing structural and metamorphic studies in more highly deformed basement terrains (e.g. Blair \& Bilodeau, 1988; Haines et al., 2001; McCann \& Saintot, 2003). The type, distribution and sequence of sedimentation reveals much about the development of accommodation

\footnotetext{
${ }^{1}$ Present address. D. W. Maidment, Geoscience Australia, GPO Box 378, Canberra, ACT, 2601, Australia. E-mail:

David.Maidment@ga.gov.au
}

space in response to basin forming processes, and in fossiliferous successions can place valuable constraints on the timing of tectonic processes.

$\mathrm{U}-\mathrm{Pb}$ dating of detrital zircon is one method for determining the provenance of sedimentary sequences, and when used in conjunction with sedimentological studies is a powerful tool for analysing the timing and nature of orogenic events (Ross \& Bowring, 1990; Mahoney et al., 1999; Sircombe \& Freeman, 1999; DeGraaff-Surpless etal., 2002; Goodge et al., 2004a, b). The distribution of ages of detrital zircon in a sedimentary rock reflects zircon ages in its source region(s) which, if sufficiently characteristic, can be used to identify the provenance. Sediment input 
into a basin is strongly influenced by uplift or subsidence of local basement domains, but may also be derived from sources many hundreds or thousands of kilometres distant (Rainbird et al., 1992, 1997). The varying significance of basement sources in a sedimentary rock can thus be used to track tectonic and eustatic events in the basin and surrounding regions.

The Amadeus and Georgina basins, remnants of the former Centralian Superbasin of central Australia (Figs 1 and 2; Walter et al., 1995), contain a depositional record spanning the Neoproterozoic to Devonian. These basins have been affected by several intracratonic tectonic events, the most recently discovered of these being the early Ordovician Larapinta Event which resulted in granulitefacies metamorphism in the Harts Range region between the two basins (Hand etal., 1999; Mawby et al., 1999). Detrital zircon data from metasedimentary rocks in the Harts Range indicate that protoliths to the high-grade metamorphic rocks were deposited at a similar time to sediments in the Centralian Superbasin, and rapidly buried and metamorphosed beneath an epicontinental sea (Buick et al., 2001a, 2005). The nature of the Larapinta Event remains the subject of some debate, with the available data suggesting that sediment burial to mid-crustal depths took place by progressive sedimentation in an exceptionally deep basin rather than by convergent tectonism and mountain building (Hand et al., 1999; Buick etal., 2001b).

A systematic detrital zircon study of sedimentary rocks from the Amadeus and Georgina basins has been carried

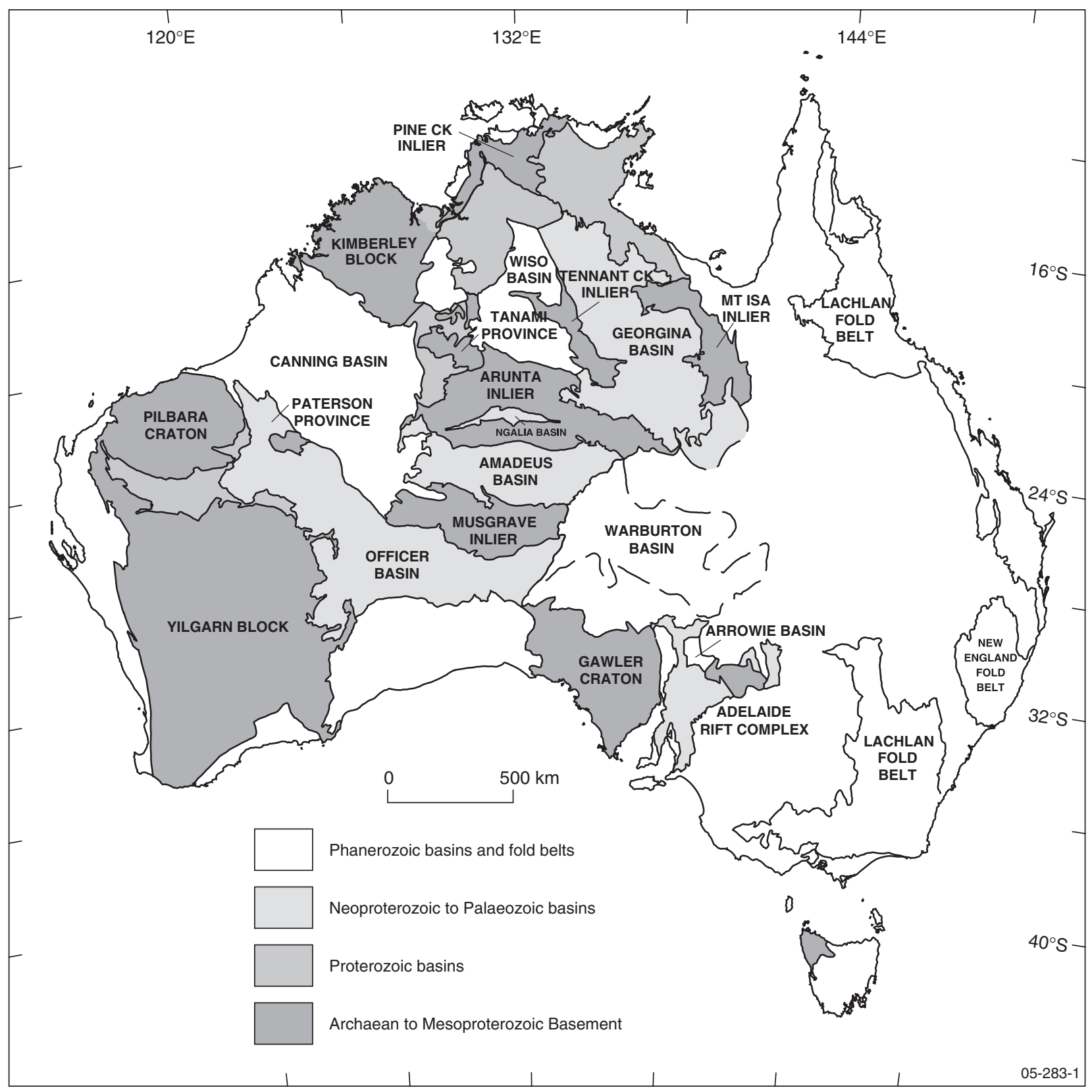

Fig. 1. Map of Australian basins and basement elements (Geoscience Australia). 


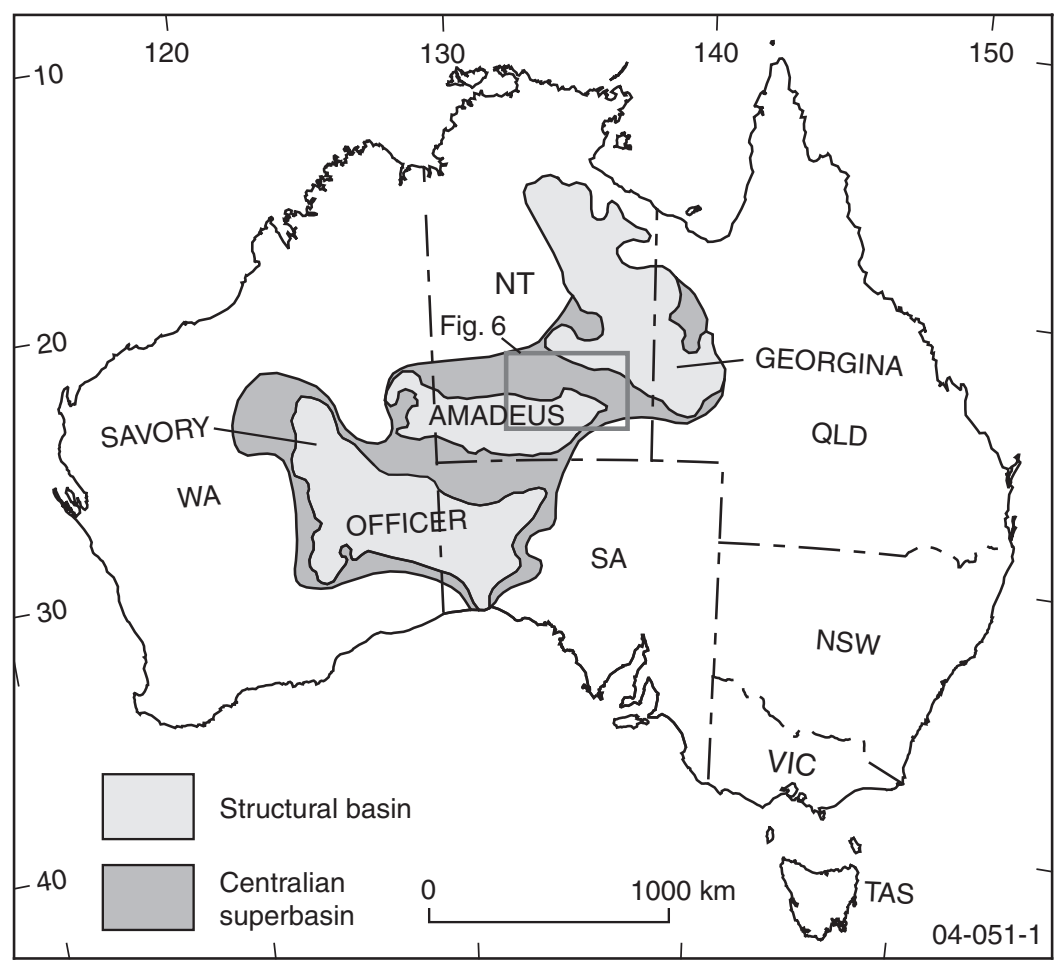

Fig. 2. Distribution of the Neoproterozoic to Palaeozoic Centralian Superbasin, showing inferred extent of the superbasin and the currently preserved constituent basins.

out to track the character and timing of tectonism in the central Australian region, and to provide a reference against which detrital zircon data from the high-grade metasedimentary rocks in the Harts Range can be compared. If the metasedimentary and adjacent sedimentary rocks are correlatives, then the relatively well-understood sedimentary history of the Amadeus and Georgina basins could then be used to provide a context in which to understand the tectonism associated with the Larapinta Event. The results of this study show that changes in provenance of the Centralian Superbasin sediments closely reflect tectonism within the basin and surrounding regions, and support the notion that the Larapinta Event took place beneath an extensionally generated depocentre.

\section{GEOLOGICAL BACKGROUND}

During the Neoproterozoic, most of central Australia was covered by an interconnected depositional system known as the Centralian Superbasin (Fig. 2; Walter et al., 1995). The remnants of this superbasin are the Georgina, Amadeus, Ngalia and Officer basins, which contain successions of continental to shallow marine sedimentary rocks with similar depositional histories. At different times, parts of the Centralian Superbasin were also linked to other basins such as the Wiso Basin to the north, the Warburton Basin to the southeast and the Adelaide Rift Complex to the south (Fig. 1; Shaw et al., 1991). This system was disrupted in the Palaeozoic by uplift of Palaeo- to Mesoproterozoic basement inliers to form the current structural basins.
The Centralian Superbasin consists of a number of depositional successions resulting from a complex interplay between tectonic and eustatic influences (Lindsay \& Korsch, 1989, 1991; Shaw et al., 1991; Walter et al., 1995). The Neoproterozoic stratigraphic succession is similar in all the component basins, suggesting a common tectonic history (Walter et al., 1995), though Lindsay (2002) considered that a superbasin only existed during the earliest stages of basin development. The Amadeus Basin is the most intensively studied of the component basins and thus forms a reference against which other basins can be compared.

Shaw et al. (1991) and Shaw (1991) identified nine tectonostratigraphic successions in the Neoproterozoic to Devonian sedimentary rocks of the Amadeus Basin, characterised by intervals of subsidence separated by periods of erosion and changes in basin morphology (Fig. 3). A similar scheme is adopted in this paper, with modification of the Neoproterozoic successions based on the subdivision of Walter et al. (1995) and Walter \& Veevers (1997). Although deposition of these sediments occurred over a period of 450-500 million years, sedimentation was episodic, with active sedimentation totalling less than half of this period. Succession $1(1.0-0.8 \mathrm{Ga})$ is characterised by broad subsidence or downwarping, possibly a result of thermal subsidence following plume-related magmatism recorded in the $\sim 0.8 \mathrm{Ga}$ Amata and Gairdner dyke swarms of central and southern Australia (Zhao et al., 1994; Lindsay, 1999). The second and third successions (700$650 \mathrm{Ma}, 580-570 \mathrm{Ma}$ ) are largely the consequence of global glaciation events, the Snowball I and II events of Hoffman 


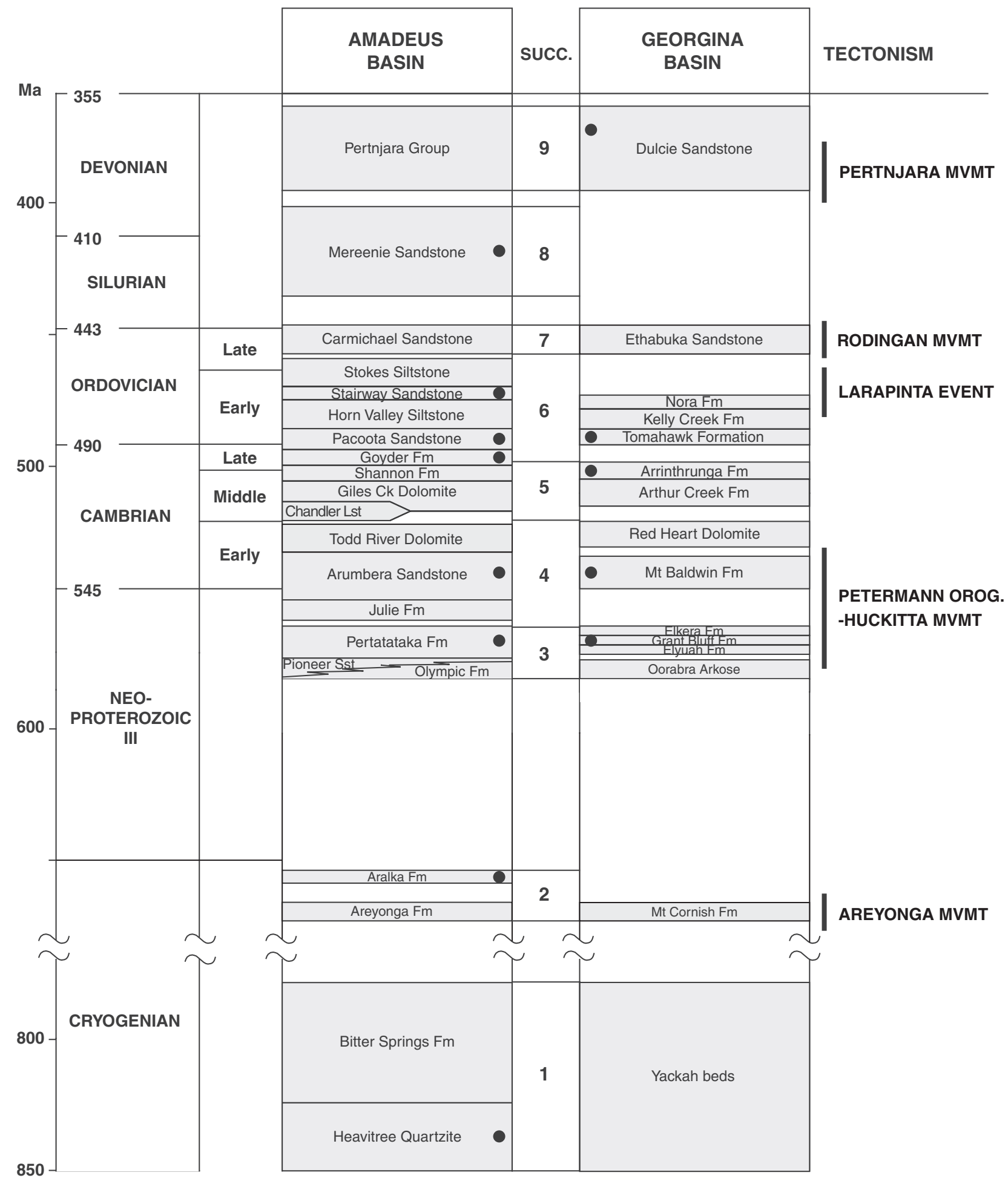

Sample - this study

Fig. 3. Stratigraphy of the northeastern Amadeus Basin and the southwestern Georgina Basin (after Freeman, 1986; Shaw, 1991; Kruse \& Mohammed, 2005). The stratigraphy is grouped into nine successions based on the classification of Shaw (1991), Walter et al. (1995) and Walter \& Veevers (1997).

et al. (1998) and subsequent eustatic sea level rise following deglaciation (Walter \& Veevers, 2000). Successions 4 and 5 (550-530 Ma, 510-497 Ma) appear to reflect more localised tectonic influences, including uplift of nearby regions and the formation of deeper sub-basins. Succession 6 sedi- mentation (497-455 Ma) took place largely within a shallow epicratonic sea, and abruptly ceased with the onset of crustal shortening and syn-orogenic sedimentation of Successions 7, 8 and 9 between 455 and $360 \mathrm{Ma}$ during the $\sim 450-300 \mathrm{Ma}$ Alice Springs Orogeny (Bradshaw \& 
Evans, 1988; Haines et al., 2001). Although tectonism continued until at least $\sim 320 \mathrm{Ma}$, there are no preserved Carboniferous syn-orogenic sedimentary rocks. However, vitrinite and conodont maturation studies (Gorter, 1984; Jackson et al., 1984), apatite fission track data (Tingate, 1991) and K-feldspar thermal modelling (Shaw, 1987) suggest that at least an additional $2 \mathrm{~km}$ thickness of sediment once overlay the uppermost parts of the preserved succession in the northern Amadeus Basin. This implies that a significant thickness of Carboniferous sediment was deposited towards the end of the Alice Springs Orogeny.

Several tectonic models have been proposed for the formation of the Centralian Superbasin, with attention mainly focussed on the well-documented Amadeus Basin. Extensional models for the Amadeus Basin include aulacogen models (Rutland, 1976; Veevers, 1976; Doutch \& Nicholas, 1978; Bozhkov, 1986), and a pull-apart basin model (Veevers, 1984). Lambeck $(1983,1984)$ and McQueen \& Beaumont (1989) proposed compressional models for basin formation, involving crustal warping and block faulting as a result of north-south shortening. Lindsay et al. (1987) considered that the Centralian Superbasin formed as a result of two rifting events: one at the initiation of the superbasin $(\sim 850 \mathrm{Ma})$, and one at $\sim 600 \mathrm{Ma}$, followed by an extended period of basin inversion beginning at $\sim 450 \mathrm{Ma}$. Shaw et al. (1991) concluded that no single tectonic mechanism could be invoked to explain the multiple phases of subsidence in the Amadeus Basin. Instead, they considered the Amadeus Basin to be a series of 'successor basins', with differing tectonic regimes during each phase of subsidence.

The relatively recent discovery that high grade metasedimentary rocks of the Harts Range Group between the Amadeus and Georgina basins are not Palaeoproterozoic, but as young as Cambrian in age and metamorphosed during the Early Ordovician, has necessitated re-evaluation of the Palaeozoic geodynamic setting of central Australia (Hand et al., 1999; Mawby et al., 1999; Buick et al., 2001a). Key to any Palaeozoic tectonic reconstruction is an understanding of the development of the Amadeus and Georgina basins during this period. SHRIMP U-Pb dating of detrital zircon from a range of sedimentary units within the Georgina and Amadeus basins has thus been employed to track changes in provenance that reflect the effects of tectonism. These provenance signatures also provide a reference, allowing the evaluation of potential correlations between the metamorphosed and unmetamorphosed sedimentary rocks.

\section{POTENTIAL SEDIMENT SOURCES}

There are a number of basement inliers which could have acted as sediment sources for the Centralian Superbasin. Many of these have characteristic crustal formation ages which would aid their recognition in detrital zircon age populations. Expected zircon age distribution histograms for these regions have been generated by Pell et al. (1997) and Camacho et al. (2002), which have been used as a basis for the generalised reference distributions presented in Fig. 4.

Although magmatic, and to a lesser extent metamorphic events, will dominate the expected zircon age spectrum of a terrane, older populations of zircon recycled from sedimentary and metasedimentary rocks will also contribute to the signature. It should also be borne in mind that zircon age populations in sedimentary rocks have a certain amount of inherent bias, with highuranium grains that have suffered radiation damage being less likely to survive transportation than lower-uranium grains. Older grains that have undergone multiple cycles of sediment reworking and abrasion are also less likely to be preserved than younger grains undergoing their first cycle of weathering and deposition.

Note that in this study we use the term 'Grenvillianage' to refer to zircon populations with an age range of $\sim 1.2-1.0 \mathrm{Ga}$, similar to that of the Grenvillian Orogeny in North America, which has time correlatives in several areas of Australia.

\section{Arunta Inlier}

The extensive Arunta Inlier to the north of the Amadeus Basin (Fig. 1) has a prolonged Palaeoproterozoic to Palaeozoic tectonothermal history (Collins \& Shaw, 1995; Scrimgeour, 2003). The bulk of crustal formation and metamorphism took place between $\sim 2.0$ and $1.5 \mathrm{Ga}$, with peaks at $\sim 1.79$ and $\sim 1.58 \mathrm{Ga}$ (Camacho et al., 2002). Although the $\sim 1.59-1.57 \mathrm{Ga}$ Chewings Event was a major metamorphic event, there was little associated magmatism, meaning that zircon formation was mostly as metamorphic overgrowths, which are vulnerable to abrasion during sediment transportation and are thus unlikely to be a significant component in sediment derived from the Arunta Inlier. Detrital zircon from metasedimentary rocks of the Arunta Inlier has dominant age peaks at $\sim 1.9-1.8$ and $\sim 2.5 \mathrm{Ga}$ (Claoué-Long et al., 2005). A younger terrane in the southwestern Arunta Inlier has intrusive and volcanic ages of 1.69-1.66 and 1.64-1.63 Ga (Close et al., 2003a), which distinguishes it from the rest of the inlier. Volumetrically minor magmatism at $\sim 1135 \mathrm{Ma}$ occurred along the southern margin of the Arunta Inlier (Black \& Shaw, 1992, 1995; Claoué-Long \& Hoatson, 2005).

\section{Musgrave Inlier}

The Musgrave Inlier to the southwest of the Amadeus Basin is a Mesoproterozoic terrane that experienced a markedly different history from the Arunta Inlier. There was widespread felsic magmatism between 1.20 and $1.05 \mathrm{Ga}$, including major peaks at 1.18 and $1.07 \mathrm{Ga}$ and minor peaks at 1.58 and $1.30 \mathrm{Ga}$ (Camacho et al., 2002). The $1.07 \mathrm{Ga}$ age component is characteristic of the Musgrave Inlier and serves to distinguish it from surrounding basement terranes (Camacho et al., 2002). Recent detrital zircon analysis of metasedimentary rocks from the Musgrave 


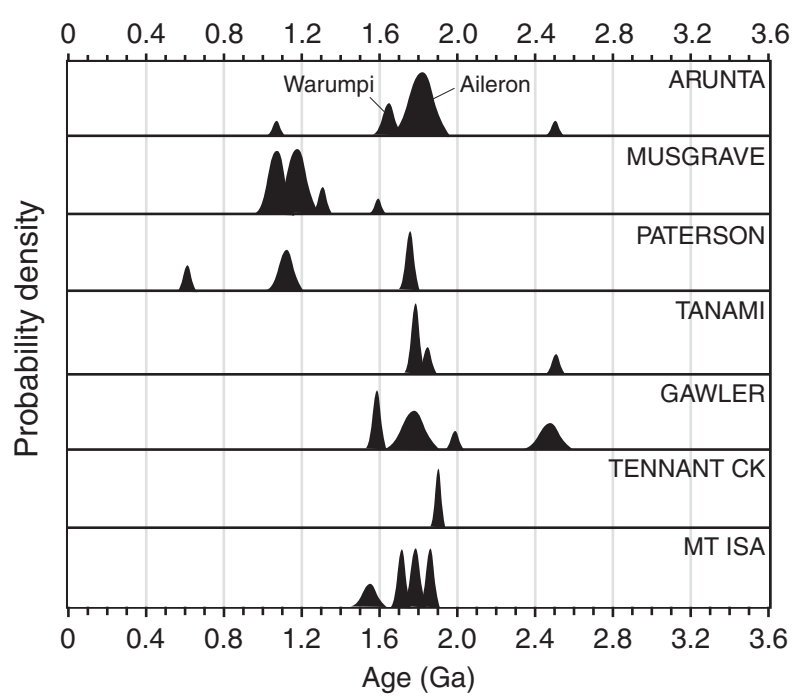

Fig. 4. Schematic representation of expected zircon probability density plots for potential source areas in the central Australian region (see Fig. 1), based on compilations of zircon $\mathrm{U}-\mathrm{Pb}$ ages by Pell et al. (1997) and Camacho et al. (2002). Vertical scale indicates relative probability.

Inlier (Schwarz \& Jagodzinski, 2006) shows significant inherited components with ages between 1.9 and $1.35 \mathrm{Ga}$.

\section{Paterson Orogen}

The Palaeo- to Mesoproterozoic Paterson Orogen to the west of the Amadeus Basin (Fig. 1) is dominated by Palaeoproterozoic ages with a relatively narrow peak at $\sim 1.80$ $1.76 \mathrm{Ga}$ (Nelson, 1995). There was minor Grenvillian-age $(\sim 1.2-1.0 \mathrm{Ga})$ tectonism, and relatively restricted felsic magmatism at $\sim 650-630 \mathrm{Ma}$ (Dunphy \& McNaughton, 1998). The relative paucity of geochronological data from the Paterson Orogen means that the expected zircon signature of this terrane is less well defined than others in the region.

\section{Tennant Creek Inlier}

TheTennant Creek Inlier to the west of the Georgina Basin (Fig. 1) has a relatively narrow range of ages, with the bulk between 1.88 and $1.82 \mathrm{Ga}$, and a peak at $\sim 1.85 \mathrm{Ga}$ (Compston, 1995). Detrital zircon from metasedimentary rocks in the Tennant Creek Inlier is dominated by 1.90-1.85 Ga ages (Compston, 1995).

\section{Mount Isa Inlier}

Zircon ages in the Mount Isa Inlier to the northeast of the Georgina Basin (Fig. 1) range between 1.87 and $1.50 \mathrm{Ga}$, with peaks at $\sim 1.87-1.84, \sim 1.80-1.78, \sim 1.76-$ $1.72, \sim 1.67-1.65$ and $\sim 1.6-1.5 \mathrm{Ga}$ (Page et al., 2000), broadly similar to that of the Arunta Inlier.

\section{Gawler Craton}

The Gawler Craton located to the south of the Amadeus Basin (Fig. 1) is a late Archaean to Mesoproterozoic province that includes metasedimentary rocks which were deposited after $\sim 2.64 \mathrm{Ga}$ (Swain et al., 2004). Metamorphism and granite intrusion occurred between 2.6 and $2.4 \mathrm{Ga}$, with gneiss ages between 2.5-2.4 and 2.01-1.96 Ga (Daly et al., 1998). Later deformation and voluminous granite intrusion occurred between 1.85 and $1.69 \mathrm{Ga}$, minor felsic magmatism at $1.65 \mathrm{Ga}$ and voluminous felsic and mafic magmatism at $\sim 1.59 \mathrm{Ga}$ (Daly et al., 1998).

\section{Tanami Province}

Felsic intrusive and extrusive rocks in the Tanami Province (Fig. 1) range in age between $\sim 1.84$ and $1.80 \mathrm{Ga}$ (Cross et al., 2003). Low-grade metasedimentary rocks in the region are dominated by detrital zircon ages between $\sim 1.9$ and $\sim 1.85 \mathrm{Ga}$, with secondary peaks at $\sim 2.5$ and $\sim 2.2 \mathrm{Ga}$ (Cross \& Crispe, 2007).

\section{PREVIOUS PROVENANCE STUDIES}

A limited amount of isotopic provenance work has been carried out in the Amadeus Basin, mainly in the far southwestern and central-northern parts of the basin, but there are no data for the northeastern part of the basin or the Georgina Basin. Zhao et al. (1992) collected whole-rock $\mathrm{Sm}-\mathrm{Nd}$ and detrital zircon $\mathrm{U}-\mathrm{Pb}$ data for Neoproterozoic and Cambrian sedimentary rocks from the Amadeus Basin. Their Sm-Nd data suggest provenance from both the Arunta and the Musgrave inliers, with the proportion of detritus sourced from the Musgrave Inlier increasing up-section. Detrital zircon analyses of two units (the Neoproterozoic Heavitree Quartzite and Cambro-Ordovician Goyder Formation) provided a basis for interpreting the $\mathrm{Sm}-\mathrm{Nd}$ data, with the Heavitree Quartzite dominated by zircon of Arunta Inlier age $(\sim 1.9-1.5 \mathrm{Ga})$ and the Goyder Formation containing a range of younger zircon ages, consistent with ages known from the Musgrave Inlier.

Barovich \& Foden (2000) examined the $\mathrm{Nd}$ isotopic compositions of Cambrian and Ordovician rocks from the Amadeus Basin and concluded that the sediments were derived primarily from the Musgrave Inlier during the Cambrian, but had a more widespread regional source in the Ordovician.

Camacho et al. (2002) dated detrital zircon from five Neoproterozoic to Early Cambrian sedimentary units in the far southwestern part of the Amadeus Basin to test a 'thermal blanket' model of orogeny in the adjacent Musgrave Inlier. They found a major component $\sim 1.2-1.0 \mathrm{Ga}$ zircon in these sedimentary rocks, apparently sourced from the Musgrave Inlier. From this they inferred that the Musgrave Inlier was emergent before and during the 570 $530 \mathrm{Ma}$ Petermann Orogeny, rather than buried beneath an insulating sediment layer. 
Detrital zircon from the latest Neoproterozoic to Early Cambrian Arumbera Sandstone and Late Cambrian Pacoota Sandstone at Ellery Creek, $\sim 80 \mathrm{~km}$ west of Alice Springs, was dated by Buick et al. (2005) to evaluate potential correlations between the Amadeus Basin and metasediments in the Harts Range area. Broad similarities between the detrital zircon signatures support the correlation and form the starting point for the systematic study presented here.

\section{METHODOLOGY}

Zircon concentrates were prepared from $\sim 3 \mathrm{~kg}$ crushed rock samples using clean heavy liquid and magnetic mineral separation techniques. Hand picked zircon was mounted in epoxy resin with zircon standards SL13, QGNG and Temora 2. Mounts were imaged before analysis by reflected and transmitted light photomicroscopy and cathodoluminescence (CL) imaging on a Hitachi S$2250 \mathrm{~N}$ SEM at the Australian National University Electron Microscopy Unit.

$\mathrm{U}-\mathrm{Th}-\mathrm{Pb}$ isotopic analyses were carried out on the SHRIMP I and SHRIMP RG ion microprobes at the Research School of Earth Sciences using procedures similar to those described by Williams \& Claesson (1987) and Claoué-Long et al. (1995). Analytical conditions were: $10 \mathrm{kV}$ primary beam, $2-5 \mathrm{nA} \mathrm{O}{ }_{2}^{-}, \sim 30 \mu \mathrm{m}$ diameter spot, $10 \mathrm{kV}$ positive secondary ions, $5000 \mathrm{R}$, peak switching, single electron multiplier. $\mathrm{Pb}$ isotope compositions were measured directly, without correction for mass-dependant fractionation ( $\leq 0.25 \% / \mathrm{AMU})$. Fractionation of $\mathrm{Pb}$ relative to $\mathrm{U}$ and $T h$ was corrected using the relationship $\mathrm{Pb}^{+} / \mathrm{U}^{+}=\mathrm{A}\left(\mathrm{UO}^{+} / \mathrm{U}^{+}\right)^{2}$ (Claoué-Long et al., 1995), with assumed values for standards: $\mathrm{SL} 13$ (U=238 p.p.m.); QGNG $\left({ }^{206} \mathrm{~Pb} /{ }^{238} \mathrm{U}=0.33076\right)$; and Temora $2\left({ }^{206} \mathrm{~Pb} /\right.$ $\left.{ }^{238} \mathrm{U}=0.06683\right)$. Ages were calculated using the constants recommended by the IUGS Subcommission on Geochronology (Steiger \& Jäger, 1977). Analytical uncertainties in the tables and figures are one standard error precision estimates. Common lead corrections used ${ }^{204} \mathrm{~Pb}$ assuming laboratory-derived common $\mathrm{Pb}$ of Broken Hill galena composition.

At least 60 zircon grains were analysed from each sample, giving a $>95 \%$ probability of sampling any age component with $>8.5 \%$ relative abundance (Vermeesch, 2004). Analyses that have calculated ${ }^{207} \mathrm{~Pb} /{ }^{206} \mathrm{~Pb}$ and ${ }^{206} \mathrm{~Pb} /{ }^{238} \mathrm{U}$ ages indistinguishable within $95 \%$ probability were used in constructing probability density plots of age data. In most samples this approximates $<10 \%$ discordance, however, analytical sessions for three samples (Goyder Formation, Pacoota Sandstone and Tomahawk Formation) showed a relatively high proportion of surficial common $\mathrm{Pb}$, meaning that analytical uncertainties associated with the ${ }^{207} \mathrm{~Pb} /{ }^{206} \mathrm{~Pb}$ age are relatively large and thus concordance is difficult to assess.

Sample location coordinates are in UTM using the Australian Geodetic Datum (AGD66, Zone 53).

\section{RESULTS}

Samples in this study were collected from the southwestern Georgina Basin and the northeastern Amadeus Basin to provide local context for a companion detrital zircon study of metasedimentary rocks from the Harts Range. Eight of the nine principal sedimentary successions were sampled to provide information on the main depositional phases and later basin inversion.

\section{Succession 1 ( $\sim 1.0-0.75 \mathrm{Ga})$}

According to Korsch \& Lindsay (1989), the initiation of the Amadeus Basin was marked by clastic sedimentary rocks, basalts and felsic igneous rocks of the Mount Harris Basalt, Bloods Range beds and Dixon Range beds in the far southwestern and northwestern margins of the basin. They related this bimodal magmatism to rifting and correlated the basalts with the Stuart Dyke Swarm in the underlying Arunta Inlier, which has a Sm-Nd mineral isochron age of $1076 \pm 33 \mathrm{Ma}$ (Zhao \& McCulloch, 1993). Recent dating of felsic rocks from the basal succession is consistent with this interpretation, yielding ages between $\sim 1090$ and $\sim 1040 \mathrm{Ma}$ (Close et al., 2005). This relatively thick package of volcanic and sedimentary rocks, known as the Tjauwata Group in the Northern Territory, appears to be a correlative of the Tollu Group in Western Australia, which contains felsic volcanics with an age of $1075 \pm 5 \mathrm{Ma}$ (Shaw, 1991; Shaw et al., 1991; Close et al., 2003b, 2005).

This 'rift sequence' is unconformably overlain by a sheet of fluvial to marine sandstone, which is present in all the component basins, however, there are relatively few data to constrain its depositional age. In the Amadeus Basin, this unit is represented by the Heavitree Quartzite, which unconformably overlies the $1076 \pm 33 \mathrm{Ma}$ Stuart Dyke Swarm in the southern Arunta Inlier and the Kulgera Dyke Swarm in the Musgrave Inlier, on which a $\mathrm{Rb}-\mathrm{Sr}$ age of $1054 \pm 14 \mathrm{Ma}$ (Camacho et al., 1991) and a Sm-Nd age $1090 \pm 32 \mathrm{Ma}$ (Zhao \& McCulloch, 1993) has been measured. The Bitter Springs Formation of the Amadeus Basin overlies the Heavitree Quartzite and contains spilitic volcanics with geochemical similarities to the Amata dyke swarm in the central Musgrave Inlier, which has a baddeleyite $\mathrm{U}-\mathrm{Pb}$ age of $824 \pm 4 \mathrm{Ma}$ (Glikson et al., 1996) and $\mathrm{Sm}-\mathrm{Nd}$ ages of $790 \pm 40$ and $797 \pm 49 \mathrm{Ma}$ (Zhao et al., 1994). These data, as well as stratigraphic correlations with the Adelaide Rift Complex and stromatolite biostratigraphy, suggest that the Bitter Springs Formation was deposited at $\sim 825-800 \mathrm{Ma}$ (Zhao et al., 1994; Walter et al., 1995). This constrains the Heavitree Quartzite to have been deposited between $\sim 1050$ and $\sim 800 \mathrm{Ma}$. If the Heavitree Quartzite was deposited at $\sim 0.85-0.80 \mathrm{Ga}$, as favoured by many workers (e.g. Lindsay \& Korsch, 1991; Walter \& Veevers, 2000), then initiation of the broader Centralian Superbasin might be largely unrelated to the earlier $(\sim 1.1 \mathrm{Ga})$ phase of extension. However, there is a major disconformity in the Bitter Springs Formation below the spilites (Southgate, 1991), which means that the Heavitree 
Quartzite was possibly deposited considerably earlier than 0.85-0.80 Ga (Close et al., 2005).

The earliest 'rift sequence' of the western Amadeus Basin has not been examined in this study, and the Heavitree Quartzite and carbonates, evaporites, siltstones and spilites of the Bitter Springs Formation have been assigned to Succession 1, consistent with the terminology of Shaw (1991). In the Georgina Basin Succession 1 is represented by the Yackah beds, which consist of a basal sandstone overlain by a relatively thin carbonate unit.

\section{Heavitree Quartzite-Amadeus Basin ( 1.0-0.80 Ga) - Sample 2002080308}

The Heavitree Quartzite was sampled near Ruby Gap Gorge, within the Palaeozoic Arltunga Nappe Complex on the northeastern margin of the Amadeus Basin (Fig. 6) (Forman, 1971). The quartzite in this area is part of the essentially unmetamorphosed and weakly deformed basal thrust sheet of the Ruby Gap Nappe, an antiformal stack of thrust sheets which have been increasingly deformed and metamorphosed to upper greenschist facies towards the north (Dunlap et al., 1995). The quartzite was sampled from a thickly bedded unit with ripple-marks on bedding plane surfaces (Fig. 6; GR 498968 7403777), and is interpreted to have been deposited in a high-energy, open, shelf-like environment on a broad, low-gradient ramp (Lindsay, 1999).

The analyses of 66 grains are listed in Table S1. Most zircon ages lie within three major groupings: a dominant group between 1.68 and $1.50 \mathrm{Ga}(\sim 59 \%)$ with a mode at $\sim 1.63 \mathrm{Ga}$, a secondary group at $\sim 1.82-1.72(\sim 23 \%)$ with a mode at $\sim 1.78 \mathrm{Ga}$, and a smaller group at $\sim 1.24-1.12 \mathrm{Ga}$ ( $\sim 12 \%$ ) (Fig. $9 \mathrm{~h}$ ). The two main age groups were possibly derived from the Arunta Inlier, with ages between $\sim 1.68$ and $1.63 \mathrm{Ga}$ consistent with sources in the Warumpi Province of the southwestern Arunta Inlier, and ages between $\sim 1.82$ and $1.72 \mathrm{Ga}$ consistent with derivation from felsic magmatic rocks in the broader Arunta Inlier and North Australian Craton. Ages between $\sim 1.24$ and $\sim 1.12 \mathrm{Ga}$ are similar to those recognised in the Musgrave Inlier, but lack the characteristic $1.07 \mathrm{Ga}$ population, suggesting that either $1.07 \mathrm{Ga}$ rocks were not exposed at the time of deposition or the Musgrave Inlier was not the source of Mesoproterozoic zircon.

Orientations of low-angle, large-scale sigmoidal foresets and isopach data indicate a northeasterly source for the Heavitree Quartzite (Lindsay, 1999), but the only known exposed basement of appropriate age to the northeast is the 1.25-1.10 Ga Cape River Metamorphics of the western Lolworth-Ravenswood Block in north Queensland (Hutton et al., 1998). The close match of zircon ages with known magmatism in the central Australian region suggests a dominantly local source, implying that the palaeocurrent data do not point to the source region of the sediments. This interpretation is consistent with that of Lindsay (1999, 2002), who envisaged that regional uplift related to plume development caused peneplanation of cen- tral Australia, generating large volumes of sediment which were subsequently deposited as a broad sand sheet in a superbasin formed by thermal subsidence. The Heavitree Quartzite and equivalents were interpreted to have been deposited in an extensive shelf-like setting, with repeated reworking and redistribution of sands by tidal currents. The similarity of the detrital zircon age signature of the Ruby Gap sample and a sample of Heavitree Quartzite from Alice Springs (Zhao et al., 1992) is also consistent with this interpreted depositional setting, which would tend to homogenise the detrital signature. The 1.28-1.12 Ga zircon is thus considered most likely to have been derived from the Musgrave Inlier, though a more distal source cannot be ruled out.

The youngest analysis at $\sim 1.12 \mathrm{Ga}$ is significantly older than the inferred depositional age and does not constrain the depositional age more precisely than that inferred from other information. This possibly reflects a lack of exposed early Neoproterozoic source material in central Australia, but leaves open the possibility that the quartzite was deposited significantly earlier than $\sim 850 \mathrm{Ma}$.

\section{Succession $2(\sim 700-650 \mathrm{Ma})$}

Succession 2 unconformably overlies Succession 1 and is marked by deposits of the Sturtian glaciation, i.e. the Snow ball I event of Hoffman et al. (1998). In the northeastern part of the Amadeus Basin, the succession reaches a thickness of $\sim 1600 \mathrm{~m}$, and is interpreted to have been deposited within similar fault-bounded troughs to its correlatives in the Georgina Basin (Walter, 1980; Walter et al., 1995). In the northeastern Amadeus Basin it consists of tillites of the Areyonga Formation and overlying siliciclastics and stromatolitic carbonates of the Aralka Formation (Fig. 3). In the southwestern Amadeus Basin, diamictite, sandstone and shale of the Inindia beds are the probable correlatives of the Areyonga and Aralka formations (Wells et al., 1970; Walter et al., 1995). The depositional age of the Aralka Formation has recently been determined by Re-Os dating of black shales as $658 \pm 6 \mathrm{Ma}$ (Kendall \& Creaser, 2004). A significantly lower Re-Os age of $592 \pm 14 \mathrm{Ma}$ for the Aralka formation (Schaefer \& Burgess, 2003), was possibly affected by incorporation of detrital Os and/or Re (Kendall \& Creaser, 2004). It is during this period that the so-called 'Central Ridge' formed in the Amadeus Basin, a broadly east-west-trending structural high which separates the MacDonnell sub-basin in the north from the Mount Conner sub-basin in the south (Fig. 5; Oaks et al., 1991).

\section{Limbla Member-Amadeus Basin ( 660-650 Ma) - Sample 86500599}

The Limbla Member is a distinctive sandstone unit within tillites of the Aralka Formation. A sample from the Hale River area in the northeastern part of the basin (Fig. 6; GR 5112507339500 ) consists of a fine-grained feldspathic sandstone with small-scale planar cross beds and herring- 

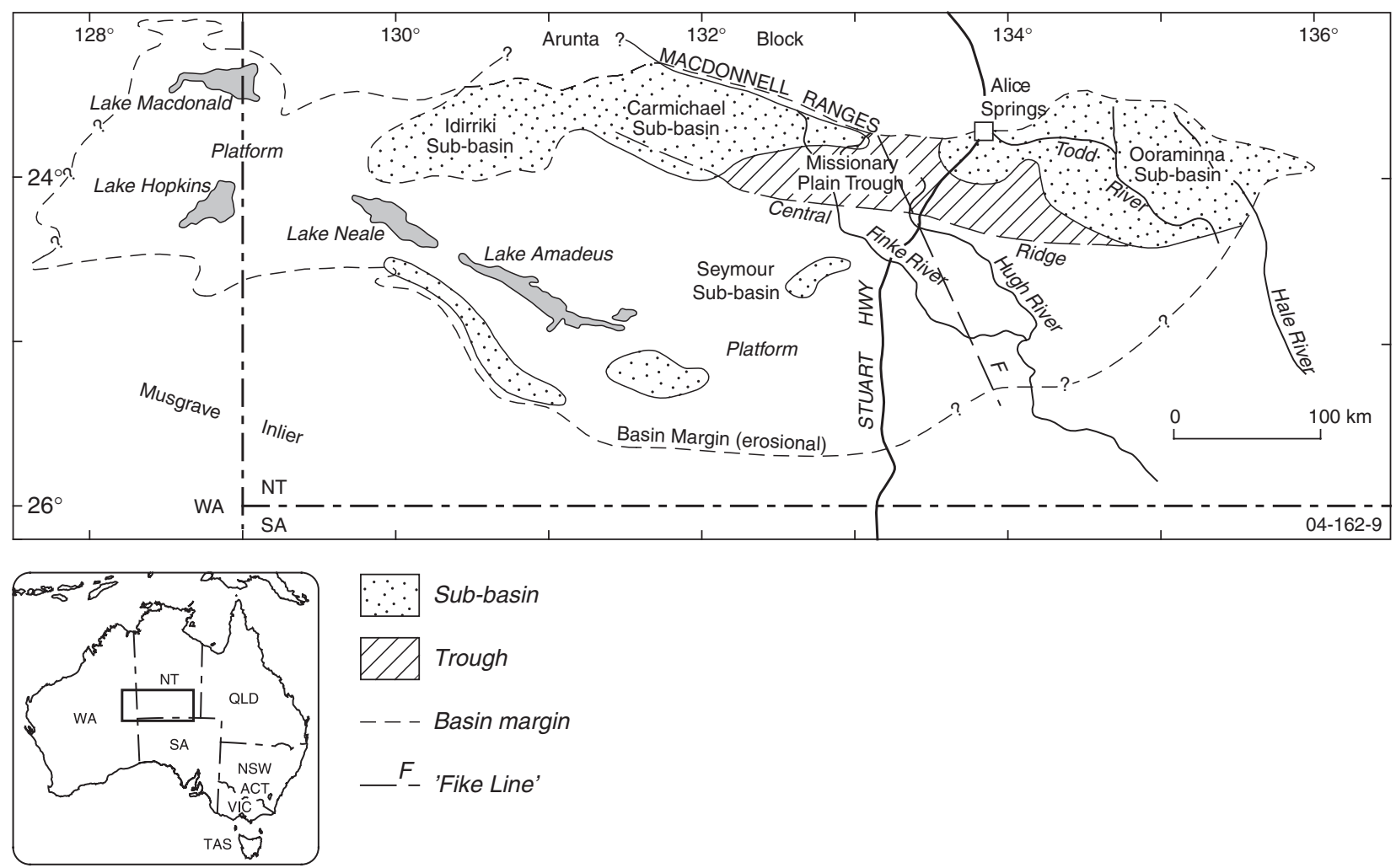

Fig. 5. Major morphological features of the Amadeus Basin, after Lindsay \& Korsch (1991).

bone cross beds, consistent with deposition within a tidal environment. Analyses of 63 grains are listed in Table S2. The zircon grains have a range of ages between 2.50 and $1.08 \mathrm{Ga}$, with modes at $\sim 1.76, \sim 1.58, \sim 1.40, \sim 1.18$ and $\sim 1.08$ Ga (Fig. 9g). The Palaeoproterozoic grains were possibly derived from the Arunta Inlier, whereas Grenvillian-aged zircon was probably derived from the Musgrave Inlier. A grouping at $\sim 1.58 \mathrm{Ga}(\sim 18 \%)$ and a smaller group with ages between 1.47 and $1.34 \mathrm{Ga}(\sim 12 \%)$ have similar ages to detrital zircon in metasediments from the Musgrave Inlier (Schwarz \& Jagodzinski, 2006) and might be reworked detrital grains. The youngest detrital zircon at $\sim 1.07 \mathrm{Ga}$ is significantly older than the inferred depositional age.

The presence of zircon grains with apparent sources in both the Arunta and Musgrave inliers is consistent with the interpreted palaeogeographic setting for the Areyonga Formation proposed by Lindsay (1989), who suggested that the formation was deposited as a result of ice flow from the north and progradation of siliciclastic sediments from the south. The apparent mixing of northern (Arunta Inlier) and southern (Musgrave Inlier) sources in the Hale River area suggests that although the Central Ridge formed a significant topographic high, it did not completely block transportation of sediment between the northern and southern parts of the basin.

The presence of Grenvillian-age zircon suggests that at least part of the Musgrave Inlier was exposed at $\sim 0.65 \mathrm{Ga}$, which is consistent with detrital zircon data for the laterally equivalent Inindia beds in the southwestern part of the basin, which have a strong Grenvillian-age component that is considered to be derived from the Musgrave Inlier (Camacho et al., 2002). A progressive thickening of Succession 2 towards the southwestern part of the basin is consistent with uplift of the Musgrave Inlier during the Areyonga Movement of Wells et al. (1970), which is loosely constrained to have occurred between 0.8 and $0.6 \mathrm{Ga}$. Boulders in the Areyonga Formation were considered by Wells et al. (1970) to be derived from uplifted sedimentary rocks of Succession 1 and metamorphic rocks of the Arunta Inlier, indicating some uplift to the north, which is consistent with the $\sim 1.76 \mathrm{Ga}$ age cluster.

\section{Succession 3 ( $\sim 580-570 \mathrm{Ma})$}

The base of this succession is marked by diamictites formed during the Marinoan-age glaciation (Walter et al., 1995). Diamictites in the Amadeus Basin are restricted to the Olympic Formation in the northeastern parts of the basin and grade westward into conglomerates and arkosic sandstones of the Pioneer Formation, interpreted as glacial outwash deposits (Walter et al., 1995). The overlying Pertatataka and Julie formations form an upwards-shallowing sedimentary cycle, progressing from deep water turbidites and pelagic sediments to shallow-water platform carbonates (Lindsay \& Korsch, 1991). Coarsening of the Pertatataka Formation towards the south implies a sediment source in the Musgrave Inlier (Walter et al., 1995). In the Georgina Basin, the correlatives of the Pioneer and Olympic formations are considered to be the coarse-grained 


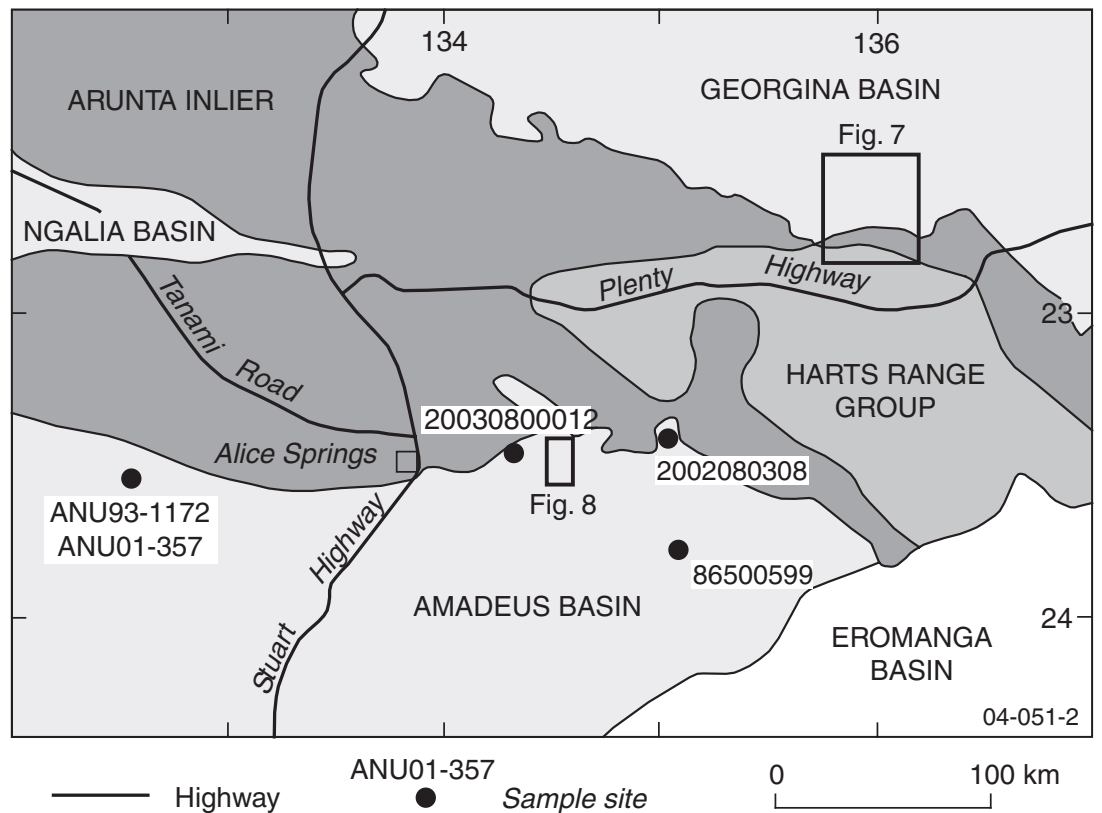

Fig. 6. Regional map of sample localities in the northeastern Amadeus Basin and southwestern Georgina Basin.

Oorabra Arkose and Black Stump Arkose (Walter, 1980). Fine-grained siliciclastic rocks of the overlying Mopunga Group contain a sandstone unit (the Grant Bluff Formation), which has been correlated with sandstone of the Cyclops Member of the Pertatataka Formation in the Amadeus Basin (Walter et al., 1995). The similar upwardfining of successions 2 and 3 were interpreted by Walter et al. (1995) to have resulted from eustatic sea-level rise after glaciation. The age of Succession 3 is constrained by the ages of the underlying and overlying successions and by a $\sim 580 \mathrm{Ma}$ age for the Marinoan glaciation in Newfoundland and Tasmania (Bowring et al., 2003; Calver et al., 2004).

Cyclops Member-Amadeus Basin ( 575 Ma) - Sample 2003080012

The Cyclops Member of the Pertatataka Formation, interpreted to have been deposited within a shallow marine environment (Lindsay \& Korsch, 1991; Walter \& Veevers, 1997) was sampled from an outcrop of thinly bedded, fine-grained quartz sandstone $\sim 20 \mathrm{~km}$ west of Ross River Homestead (GR 431523 7389612). Sixty-two analyses of zircon grains are listed in Table S3. The zircon age spectrum of concordant analyses (Fig. 9f) is dominated by ages between $\sim 1.9$ and $\sim 1.7 \mathrm{Ga}(\sim 45 \%)$, with a secondary cluster at $\sim 2.5 \mathrm{Ga}(\sim 12 \%)$, consistent with a sediment primarily sourced from the Arunta Inlier. There is a spread of ages between $\sim 1.26$ and $\sim 0.8 \mathrm{Ga}(\sim 22 \%)$, with one analysis yielding a ${ }^{206} \mathrm{~Pb} /{ }^{238} \mathrm{U}$ age of $\sim 594 \mathrm{Ma}$, which is only marginally concordant within error and might have suffered $\mathrm{Pb}$ loss. A second analysis of the same grain was grossly discordant, supporting this interpretation. Excluding this grain, the youngest concordant analysis yields an age of $\sim 807 \mathrm{Ma}$, significantly higher than the inferred depositional age of the unit $(\sim 575 \mathrm{Ma})$. The paucity of Grenvillian ages suggests that the Musgrave Inlier was not a major source of sediment for this unit, contrasting with the interpretation of Walter et al. (1995) for the unit as a whole.

\section{Grant Bluff Formation-Georgina Basin ( 575 Ma) - Sample $2002080042 B$}

The Grant Bluff Formation was sampled from the northern part of the Elua Range (Fig. 7), where it forms escarpments of resistant coarse-grained sandstone separated by fine-grained, thinly bedded, recessive sandstone units interpreted to have been deposited in a marine environment (Kruse et al., 2002). Ichnofossils recorded by Jenkins et al. (1992) are consistent with the late Neoproterozoic age assigned to the formation (Kruse et al., 2002). The dated sample is from a medium-grained, trough crossbedded sandstone layer $\sim 25 \mathrm{~cm}$ thick within a unit of more thinly bedded sandstone and siltstone exposed in a low ridge $\sim 4 \mathrm{~km}$ north of Gap Bore (GR 585298 7487309). Syneresis (desiccation?) cracks are preserved on bedding plane surfaces and the sandstone contains fine-disseminated pyrite.

Analyses of 76 grains are listed in Table S4. The zircon ages are remarkably similar to those from the Cyclops Member in the Amadeus Basin (although the analyses are much more consistently concordant), supporting the stratigraphic correlation between these units (Fig. $9 \mathrm{~m}$ ). The dominant age component is $\sim 1.90-1.78 \mathrm{Ga}(\sim 40 \%)$, with minor clusters at $\sim 2.5 \mathrm{Ga}(\sim 7 \%)$ and $\sim 1.58 \mathrm{Ga}(8 \%)$, and a range of ages down to $\sim 889 \mathrm{Ma}$. In common with the Cyclops Member, the sediments appear to have been sourced primarily from the Arunta Inlier. 


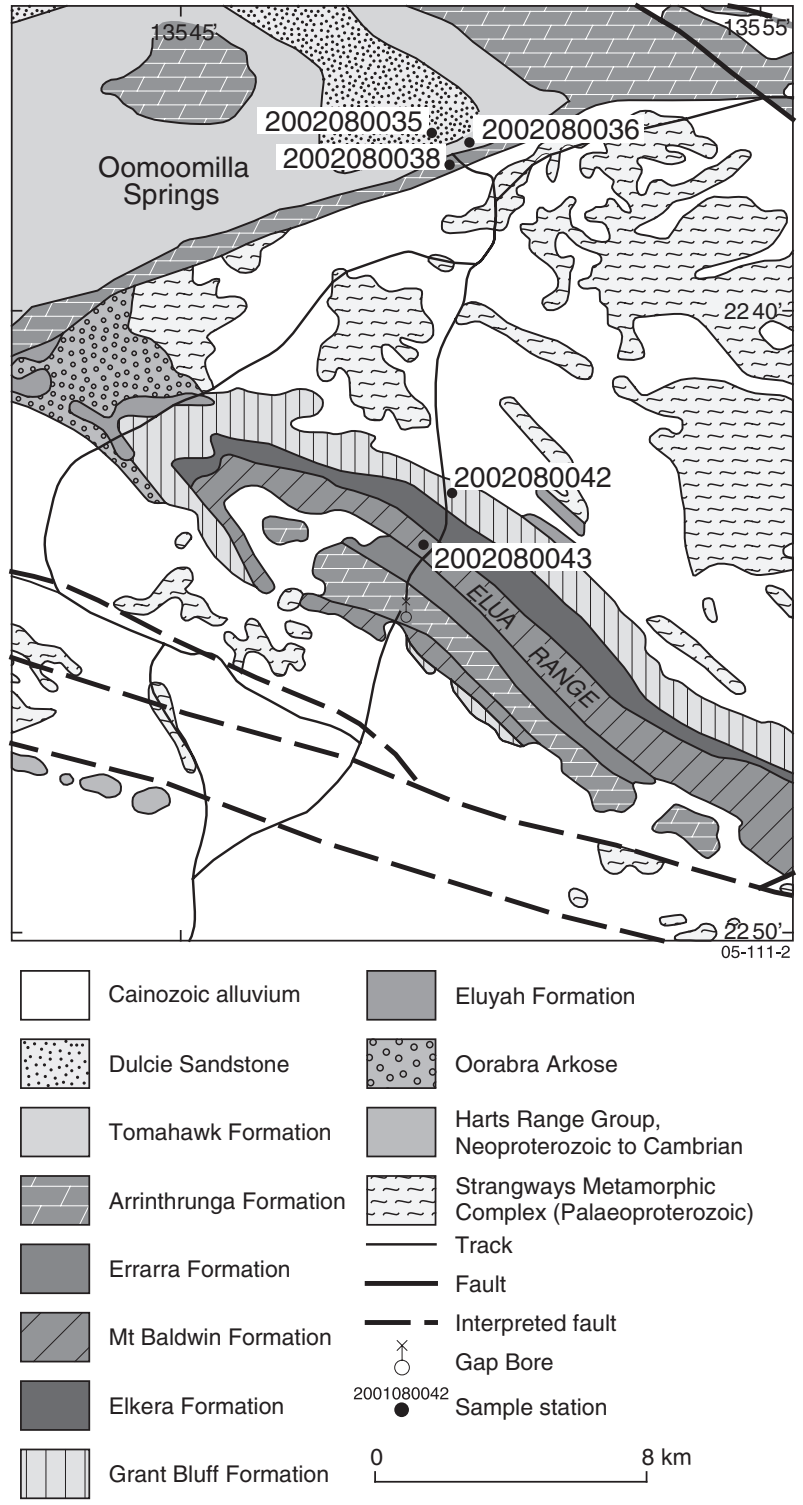

Fig. 7. Sample localities and geology of the Elua Range area of the Georgina Basin.

Both the Grant Bluff Formation and Cyclops Member contain zircon grains with ages between $\sim 1.0$ and $\sim 0.8 \mathrm{Ga}$, which have no obvious Australian sources. Although there was widespread mafic magmatism in south-central Australia at $\sim 827 \mathrm{Ma}$ (Glikson et al., 1996; Wingate et al., 1998), these mafic rocks have a low zircon content and volume, greatly reducing their significance as a zircon source. Similarly, $\sim 795 \mathrm{Ma}$ spilitic volcanics in the Bitter Springs Formation (Zhao et al., 1994), $\sim 975 \mathrm{Ma}$ dolerite intrusions in the southwestern Arunta Inlier (Wyborn et al., 1998) and $\sim 755 \mathrm{Ma}$ mafic dykes in the Pilbara Craton (Wingate \& Giddings, 2000) are also unlikely sources. The only known felsic magmatic event in Australia during this period is represented by the Rook Tuff in the Adelaide Rift Complex, which has an age of $802 \mathrm{Ma}$ (Fanning et al., 1986). It would thus appear that either there is unrecorded $1.0-0.8 \mathrm{Ga}$ felsic magmatism in central Australia or that detrital zircon of this age was derived from a more distal or exotic source.

\section{Succession 4 ( $\sim 550-530 \mathrm{Ma})$}

A relatively brief hiatus at $\sim 560 \mathrm{Ma}$ followed deposition of Succession 3, represented by an unconformity on the central ridge and a disconformity in the northern part of the Amadeus Basin (Kennard \& Lindsay, 1991). The Petermann Orogeny caused significant uplift of the Musgrave Inlier between 570 and $530 \mathrm{Ma}$ (Maboko et al., 1991; Camacho et al., 1997) forming a narrow foreland basin in the southwestern part of the Amadeus Basin. Sedimentation in the rest of the basin was largely confined to extensionally driven, rapidly subsiding sub-basins in the north (Shaw, 1991). The latest Neoproterozoic to Early Cambrian Arumbera Sandstone was deposited into these sub-basins, and has been interpreted as either the distal facies of the foreland basin sediments (Wells et al., 1970; Korsch \& Lindsay, 1989; Walter \& Veevers, 1997) or as reworked ('autocannibalised') foreland sediments (Kennard \& Lindsay, 1991; Oaks et al., 1991). The Todd River Dolomite overlies the Arumbera Sandstone, interpreted to represent a highstand deposit at the top of the succession (Kennard \& Lindsay, 1991).

In the Georgina Basin, Succession 4 is represented by siliciclastic rocks of the upper Central Mount Stuart Formation, Mount Baldwin Formation, Andagera Formation and Adam Shale, which are partly lateral equivalents. Eyre (1994) interpreted the Andagera and Mount Baldwin formations as the proximal and distal facies of an alluvial fan delta, that prograded towards the southwest.

\section{Arumbera Sandstone-Amadeus Basin ( 540 Ma) - Sample 2002080073}

Unit IV of the Arumbera Sandstone was sampled from Ross River Gorge (Fig. 8, GR 447419 7389689), where it consists of a cross-bedded, fine- to medium-grained red-brown quartz sandstone that has been interpreted as a delta front deposit (Kennard \& Lindsay, 1991). This unit is considered to be earliest Cambrian in age based on interpretations of trace fossils (Kennard \& Lindsay, 1991; McIlroy et al., 1997).

Sixty-four grains were analysed (Table S5). The detrital zircon signature is dominated by ages between $\sim 1.2$ and $\sim 1.0 \mathrm{Ga}(52 \%)$, with a range of older ages to $\sim 1.9 \mathrm{Ga}$ and two analyses at $\sim 2.5 \mathrm{Ga}$ (Fig. 9e). The relative abundance of 1.2-1.0 Ga zircon suggests a source in the Musgrave Inlier, consistent with the interpretation of Lindsay (1987) who linked stream channels in the southern part of the Amadeus Basin to deltas in the northern sub-basins. The youngest grain has a ${ }^{206} \mathrm{~Pb} /{ }^{238} \mathrm{U}$ age of $\sim 646 \mathrm{Ma}$, significantly younger than the other analysed grains, however, it has a relatively large analytical uncertainty, which makes it difficult to assess whether it has undergone Pb loss.

The detrital zircon age spectrum is similar to that obtained from the Arumbera Sandstone at Ellery Creek, $\sim 80 \mathrm{~km}$ west of Alice Springs (Buick et al., 2005), 


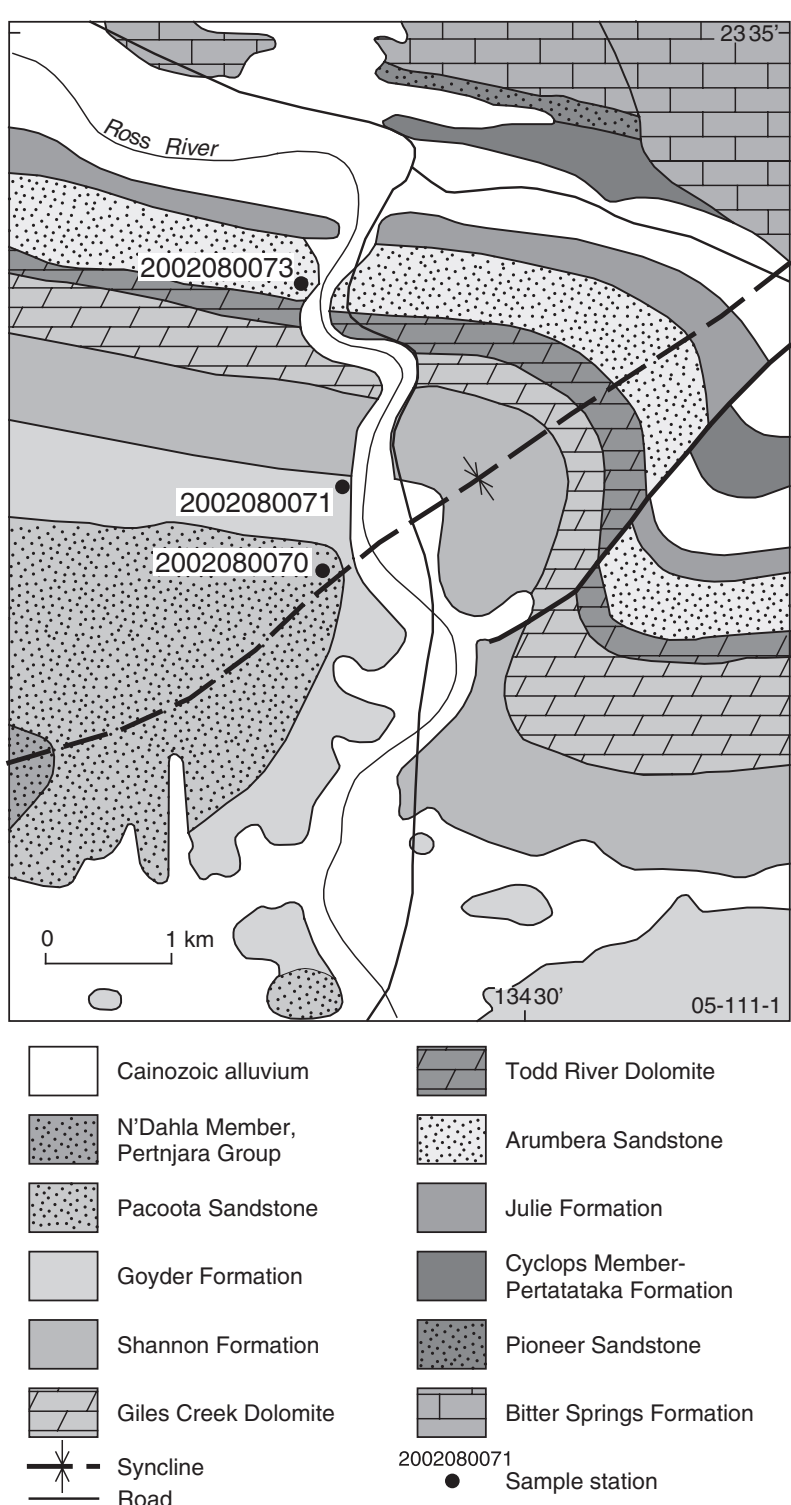

Fig. 8. Sample localities and geology of the Ross River area of the Amadeus Basin.

indicating that sediments in the northern sub-basins of the Amadeus Basin had common provenance from the southwest.

\section{Mount Baldwin Formation-Georgina Basin ( 540 Ma)- Sample 2002080043}

The Mount Baldwin Formation was sampled from a prominent ridge-forming unit of thickly bedded sandstone $\sim 2.5 \mathrm{~km}$ north of Gap Bore in the Elua Range (Fig. 7; GR 584499 7485712). The sample is a well-sorted, medium- to fine-grained quartz sandstone considered to be earliest Cambrian in age on the basis of trace fossils, and to correlate with the Arumbera Sandstone (Walter, 1980).

Analytical results for 78 grains are listed in Table S6 and plotted in Fig. 91. In contrast with the Arumbera Sandstone, the zircon age spectrum for the Mount Baldwin Formation has several age clusters and a smaller proportion of
Grenvillian ages. Peaks occur at $\sim 1.17, \sim 0.99, \sim 0.81$ and $\sim 0.67 \mathrm{Ga}$, with smaller groupings at $2.54-2.45,1.9-1.6$ and 1.48-1.31 Ga. Many of these age components are also present in the Arumbera Sandstone, though generally in much lower proportion relative to the 1.2-1.0 Ga peak. As noted above, ages between 1.0 and $0.8 \mathrm{Ga}$ have no identified sources in Australia. However, it is interesting to note that the two clusters with peaks at $\sim 810$ and $\sim 990 \mathrm{Ma}$ are similar to the ages of the only magmatism in the Musgrave Inlier in this period, which consists of mafic dykes emplaced at $\sim 1000$ and $\sim 820-800 \mathrm{Ma}$ (Glikson et al., 1996). If the sediment was largely derived from the Musgrave Inlier, these detrital ages might indicate that there is unidentified felsic magmatism or partial melting associated with the mafic magmatism. A predominantly Musgravian source for the sediment might also account for zircon grains with ages of $\sim 1.37-1.35 \mathrm{Ga}$, with similar ages identified from detrital zircon in metasedimentary rocks from the Musgrave Inlier (Schwarz \& Jagodzinski, 2006).

The Musgrave Inlier lies to the southwest, which is at odds with the northeasterly source inferred by Eyre (1994) from the distribution of sedimentary facies of the Mount Baldwin Formation and correlative units. A northeasterly source is more consistent with the absence of the characteristic Musgrave zircon peak at $\sim 1.07 \mathrm{Ga}$, however, there are no local sources of Grenvillian-age zircon in this direction. Fergusson et al. (2001) found similar populations of $\sim 1.0-0.9$ and $1.3-1.1 \mathrm{Ga}$ zircon in Cambrian metasediments from the Anakie Inlier of central Queensland, and proposed that these sediments were derived from the Ravenswood Block of northeastern Queensland. A similar source is possible for the Mount Baldwin Formation, but would imply that the sediment was derived from a much wider region than that envisaged by Eyre (1994).

Although the detrital data do not unequivocally discriminate between a southwesterly or northeasterly source, the significant difference between the detrital signatures of the Arumbera Sandstone and Mount Baldwin Formation suggests that the two units had different primary sources. This implies a that a significant change in basin development took place after $\sim 575 \mathrm{Ma}$, when the Amadeus and Georgina basins were apparently contiguous.

\section{Succession 5 (Middle to late Cambrian - $\sim 510-497 \mathrm{Ma}$ )}

Sedimentation ceased over a wide area of the Amadeus and Georgina basins during the early Middle Cambrian, and was followed by a rapid increase in the rate of subsidence and a shift in sedimentation patterns. The northern sub-basins of the Amadeus Basin became linked, and the basin expanded southwards (Shaw et al., 1991). The Georgina Basin expanded to the west and northwest, coinciding with the formation of northwest (NW)-trending grabenlike depocentres (Shaw et al., 1991). Sedimentation in the eastern Amadeus Basin and southern Georgina Basin was dominated by shallow marine carbonates, while fluvial clastic sedimentation took place west of the NW-trending 
AMADEUS BASIN
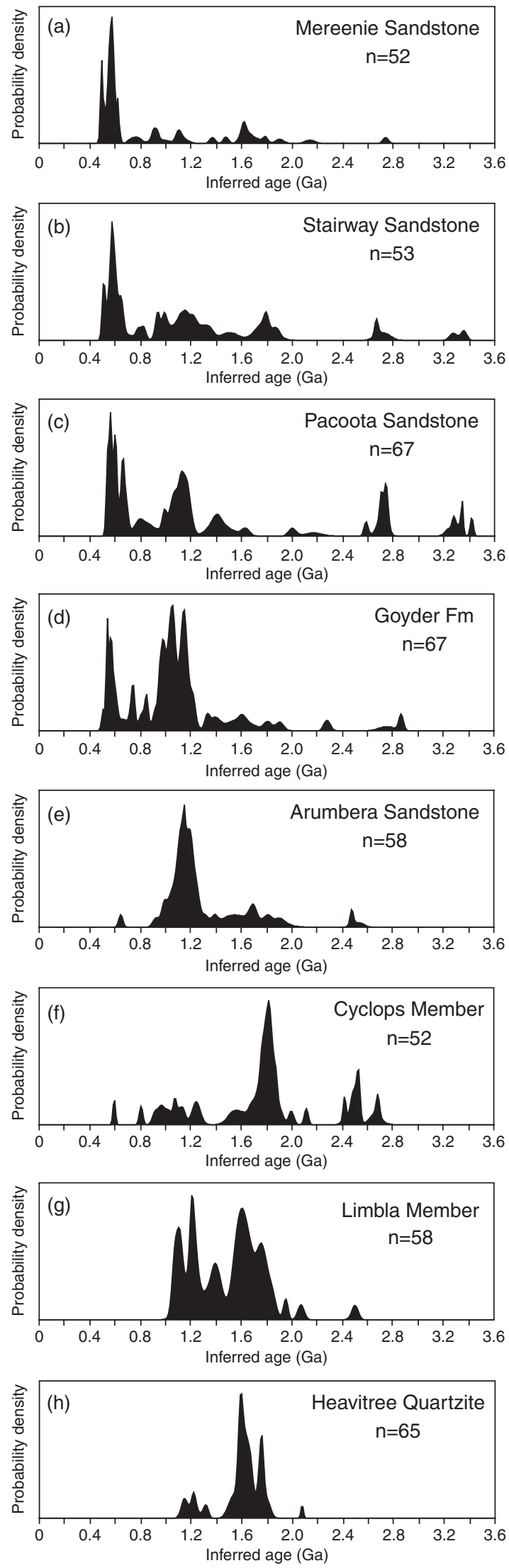
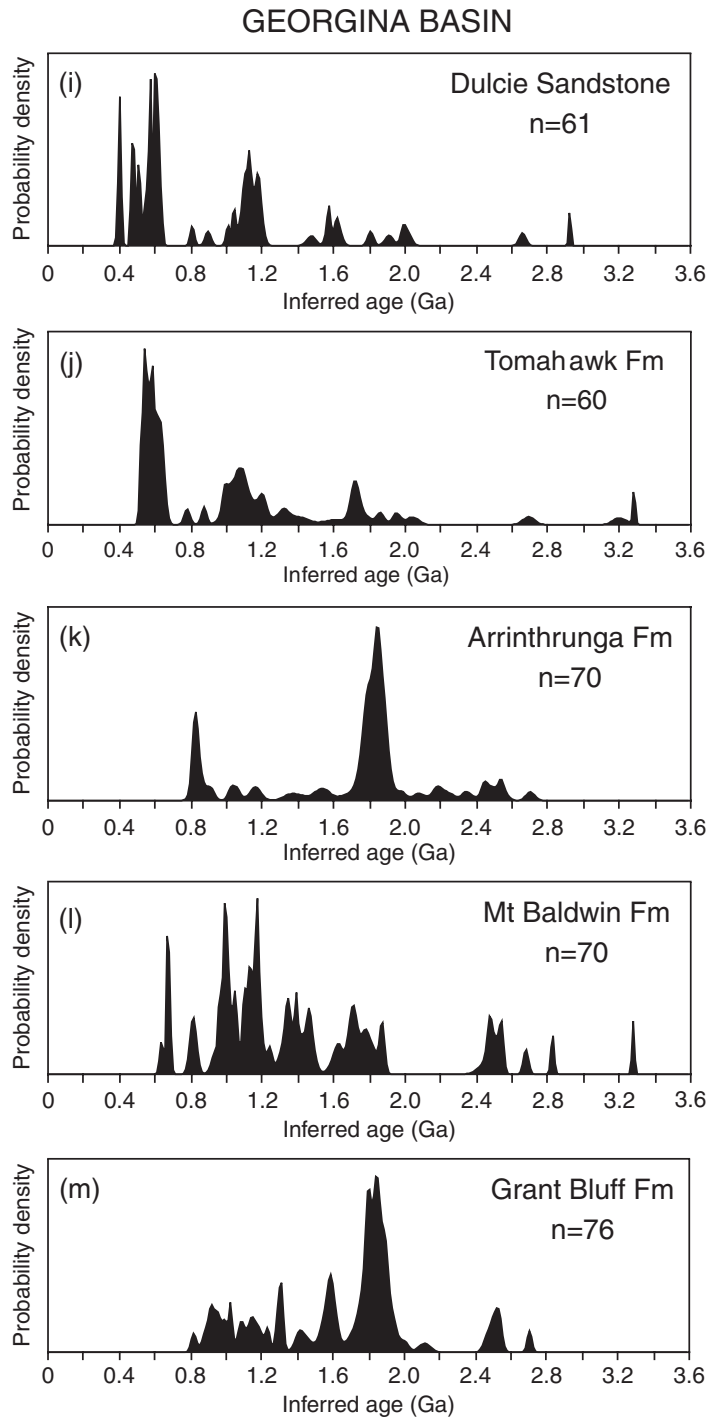
'Finke Line' in the central Amadeus Basin (Fig. 5). In the Amadeus Basin, this succession is upwards-deepening, consisting of the Giles Creek Dolomite, Shannon Formation, and lower Goyder Formation (Fig. 3). The equivalent succession in the Georgina Basin consists of the carbonate-rich Errara, Arthur Creek and Arrinthrunga Formations. The absence of siliciclastic rocks in the lower and middle parts of the Succession 5 sections examined meant that only the upper parts of the succession could be sampled for detrital zircon analysis.

\section{Lower Goyder Formation-Amadeus Basin ( 500 Ma)- Sample 2002080071}

Body fossil evidence constrains deposition of the lower Goyder Formation to the early Late Cambrian (late Mindyallian-Shergold (1986), Shergold et al. (1991)). The unit was sampled from a layered calcarenite within a crossbedded dolomite-calcarenite succession in Ross River Gorge (Fig. 8; GR 447652 7388029). The lower Goyder Formation was interpreted by Kennard \& Lindsay (1991) as a highstand marine deposit that progressively onlapped marine carbonates in the eastern part of the basin as a result of decreased supply of siliciclastic sediments derived from the west or southwest.

Analyses of 75 detrital zircon grains are listed in Table S7. The majority of $\mathrm{U}-\mathrm{Pb}$ ages are between $\sim 1.2$ and $\sim 0.95 \mathrm{Ga}(\sim 56 \%)$, with peaks at $\sim 1.14, \sim 1.06$ and $\sim 0.97 \mathrm{Ga}$ (Fig. 9d). The ages are similar to those from the Arumbera Sandstone and suggest that a large component of the sediment was sourced from the Musgrave Inlier. However, the detrital signature differs from the Arumbera Sandstone in that it contains a significant population of zircon with ages between $0.6-0.5 \mathrm{Ga}(10 \%)$, with a peak at $\sim 0.55 \mathrm{Ga}$. There are no apparent sources of this age in central Australia, with the nearest major felsic igneous province of similar age occurring in the Lachlan Fold Belt, more than $1000 \mathrm{~km}$ to the east (Fig. 1). Although the Kalkarindji flood basalt province in northern and western Australia was emplaced at approximately this time (Glass \& Phillips, 2006), these fine-grained mafic rocks are unlikely to have acted as a major source of zircon. The 0.6-0.5 Ga zircon is unlikely to be derived from distal ash-fall deposits related to volcanism in the Lachlan Fold Belt, because the volume of airfall ash deposits is typically insignificant at distances $>100 \mathrm{~km}$ downwind of a vent (Cas \& Wright, 1988). In addition, the 0.6-0.5 Ga zircon grains do not have morphologies typical of volcanic zircon (very high aspect ratios, tubular inclusions, skeletal growth (Corfu et al., 2003)), but instead have aspect ratios of $\sim 2-3$ and are rounded and pitted. It is thus considered that the 0.6-0.5 Ga zircon reflects a sedimentary input derived from rocks of this age, most likely the Pacific Gondwana margin to the east of the Amadeus Basin. Another possible source for $0.6-0.5 \mathrm{Ga}$ zircon is the Gamburtsev-Mirny drainage system of central Antarctica (Veevers, 2000). The Goyder Formation thus appears to have two major sources, reflecting a combined sediment input from the southwest and southeast. The zircon ages range as low as $\sim 509 \mathrm{Ma}$, close to the interpreted depositional age of the unit.

\section{Arrinthrunga Formation-Georgina Basin ( 500 Ma)- 2002080038)}

The Arrinthrunga Formation is a thick, well-bedded dolostone and limestone unit with minor siliciclastic beds, constrained to be between early Middle Cambrian and latest Cambrian in age (Freeman, 1986), and interpreted to have been deposited in a peritidal and restricted shallow subtidal marine environment (Kruse et al., 2002). Siliciclastic beds are rare, but a $20 \mathrm{~cm}$ thick layer of poorly exposed calcarenite was located near Oomoolmilla Springs, north of the Elua Range, which yielded a relatively small, but sufficient amount of zircon for dating (Fig. 7; GR $5854337497124)$.

The analyses of 79 grains are listed in Table S8, with a few analyses showing the effects of significant recent $\mathrm{Pb}$ loss. The detrital zircon age signature is quite different from that of the Goyder Formation, and is dominated by ages of $1.90-1.75 \mathrm{Ga}(56 \%)$, with a major peak at $\sim 1.85 \mathrm{Ga}$ (Fig. 9k), consistent with a sediment source in the Arunta Inlier. A secondary cluster at $\sim 825 \mathrm{Ma}(\sim 12 \%)$ has a similar age to that recorded in the Mount Baldwin Formation. There are no grains with ages close to the inferred depositional age of the unit. The difference in the provenance signatures of the Arrinthrunga and Goyder formations suggests that during the late Middle Cambrian, like the Early Cambrian, sedimentation patterns were not uniform across the region despite the broad lithological similarities between the two basins at this time. The Arrinthrunga Formation contains a relatively small proportion of locally derived siliciclastic material, being deposited within a shallow marine setting dominated by carbonate deposition. In contrast, the Goyder Formation has a higher siliciclastic component, containing relatively little locally derived zircon, sourcing sediment instead from the Musgrave Inlier and southeastern Australia. The differences in deposition between the two basins can be explained by variable subsidence and is addressed in more detail below.

\section{Succession 6 (Late Cambrian to mid- Ordovician - 497-455 Ma)}

Widespread erosion occurred at the end of Succession 5, at approximately the same time as the Delamerian Orogeny along the Pacific Gondwana margin. The Amadeus Basin contracted, before again expanding southwards, beyond the extents of Succession 5 (Shaw et al., 1991). The Larapinta Group, consisting of the shallow marine Pacoota Sandstone, Horn Valley Siltstone, Stairway Sandstone and Stokes Siltstone was deposited during this expansion of the basin. Progressive marine incursion into central Australia took place during this period, interpreted by many workers to have culminated in the Ordovician with the development of a WNW-trending 
transcontinental seaway, the Larapintine Sea (Keble \& Benson, 1939; Webby, 1978; Walley et al., 1991). This sea is interpreted to have linked the Amadeus Basin with the Warburton Basin to the southeast and the Canning Basin to the northwest (Fig. 1), though Veevers (1976) and Haines (2005) have questioned the linkage between the Amadeus and Canning basins based on isopach trends, the absence of outcrop or subsurface continuity and significant differences in fossil faunas found in time-correlative units. In this paper, the term Larapintine Sea is used to describe the elongate epicratonic sea, with the question of marine connectivity considered to be unresolved. In the Georgina Basin, shallow marine platform sediments were deposited during the Late Cambrian and Early Ordovician, consisting of siliciclastics of the Tomahawk beds and Nora Formation in the Dulcie Syncline area, and carbonates and siliciclastics of the Toko Group in the Toko Syncline area.

\section{Pacoota Sandstone-Amadeus Basin ( 488-486 Ma) - Sample 2002080070}

The Pacoota Sandstone is a widespread siliciclastic unit that forms the principal hydrocarbon reservoir in the Amadeus Basin. It was deposited within marine and locally fluvial environments between the Late Cambrian (Payntonian to early Datsonian) and Early Ordovician (Tremadoc to Arenig) (Deckelman et al., 1993). The Pacoota Sandstone was sampled from a medium-grained, cross-stratified quartz sandstone that forms the second lowest of four prominent sandstone units in the Ross River Gorge section (Fig. 8; GR 447713 7387555). This unit probably correlates with the P3 unit of Towler (1986) that contains trilobite and conodont fauna indicating a Late Tremadoc age (488$486 \mathrm{Ma})$

Seventy-seven analyses of zircon grains are listed in Table S9. The zircon has a larger component of $\sim 650$ $550 \mathrm{Ma}$ ages $(\sim 30 \%)$ than the Goyder Formation ( $\sim 10 \%$ ), with peaks at $\sim 660, \sim 600$ and $\sim 560 \mathrm{Ma}$, and a smaller proportion of Grenvillian-age zircon, though this still forms a significant component ( 25\%) (Fig. 9c). Small clusters also occur at $\sim 3.3(5 \%), \sim 2.74-2.70$ $(13 \%)$ and $\sim 1.4 \mathrm{Ga}(\sim 6 \%)$.

Palaeocurrent measurements for the Pacoota Sandstone in the western half of the basin indicate a generally east-directed flow (Deckelman, 1991; Deckelman et al., 1993), implying that the bulk of those sediments were derived from the west. However, the absence of any known western source of $650-550 \mathrm{Ma}$ zircon suggests that the sedimentary rocks in the northeastern Amadeus Basin, for which no palaeocurrent data are available, might instead have been derived from the Pacific Gondwana margin to the southeast. The inferred difference in provenance for the Pacoota Sandstone in the western and eastern parts of the basin possibly indicates that sediments in the northeast were deposited within the Larapintine Sea, while sediments in the western part of the basin were deposited on the platformal margin.
Tomahawk Formation-Georgina Basin ( 490 Ma) - Sample 2002080036

The Tomahawk Formation, which disconformably overlies the Arrinthrunga Formation, consists of sandstone and siltstone with lesser dolostone and limestone that crops out over a large area of the southwestern Georgina Basin. Kruse et al. (2002) revised and formalised the unit from the Tomahawk beds of Smith (1964). The age of the Tomahawk Formation is well constrained by a variety of trace and body fossils to be Late Cambrian to earliest Ordovician in age, although no definitive Ordovician fossil assemblages have yet been identified (Shergold \& Druce, 1980; Kruse et al., 2002). Kruse et al. (2002) proposed that the Tomahawk Formation formed by the shedding of terrigenous sand onto a broad marine platform, possibly from the exposed Arunta Inlier to the west. A medium-grained, planar-bedded sandstone was sampled from a thinly interbedded succession of sandstone and dolostone containing gastropod and rostroconch body fossils $\sim 4 \mathrm{~km}$ east of Oomoolmilla Springs (Fig. 7, GR 585064 7497487).

Sixty-six zircon analyses are listed in Table S10. The zircon age spectrum is very similar to that of the Pacoota Sandstone, with a large proportion of ages between 650 and $500 \mathrm{Ma}(\sim 48 \%)$, including peaks at $\sim 590$ and $\sim 540 \mathrm{Ma}$, a secondary population of Grenvillian ages ( $\sim 23 \%$ ), with a mode at $1.06 \mathrm{Ga}$, and a small population at $\sim 1.72 \mathrm{Ga}(\sim 7 \%)$ (Fig. 9j). One grain (55.1) with high-U, and very high common $\mathrm{Pb}(55.1)$ has a ${ }^{206} \mathrm{~Pb} /{ }^{238} \mathrm{U}$ age of $\sim 447 \mathrm{Ma}$, which is younger than the depositional age of the sediment and is interpreted to have undergone $\mathrm{Pb}$ loss. The Tomahawk Formation is interpreted to have a distal southeasterly source similar to the Pacoota Sandstone, with no evidence of the possible westerly provenance suggested by Kruse et al. (2002) based on limited cross-bed foreset data obtained $\sim 100 \mathrm{~km}$ to the east.

\section{Stairmay Sandstone-Amadeus Basin ( 465 Ma) - Sample ANU93-1172}

A specimen from the Stairway Sandstone was collected $\sim 80 \mathrm{~km}$ west of Alice Springs (Fig. 6; GR 302400 7364400) from the lower part of the unit, which consists of a well-sorted, fine-grained quartz sandstone with cross beds and ripple marks. Abundant body fossils including trilobites, brachiopods, sponges and cephalopods indicate a marine environment and an early Ordovician age (Darriwillian - Shergold et al., 1991).

The results of 63 analyses are listed in Table S11. The detrital zircon spectrum is similar to that of the Pacoota Sandstone and Tomahawk Formation, with a large proportion of $0.65-0.50 \mathrm{Ga}$ ages $(\sim 33 \%)$, including peaks at $\sim 510$ and $575 \mathrm{Ma}$, and populations of $\sim 1.25-$ $1.00 \mathrm{Ga}(\sim 23 \%), 1.85-1.76 \mathrm{Ga}(\sim 12 \%)$ and Archaean $(\sim 3.3, \sim 2.7 \mathrm{Ga})$ ages (Fig. $9 b)$. One grain (45.1) has a lower ${ }^{206} \mathrm{~Pb} /{ }^{238} \mathrm{U}$ age of $\sim 485 \mathrm{Ma}$ and has probably suffered $\mathrm{Pb}$ loss, although the uncertainty in ${ }^{207} \mathrm{~Pb} /{ }^{206} \mathrm{~Pb}$ is too large for this to be certain. 


\section{Succession 7 (Late Ordovician 455-435 Ma)}

A profound change in basin dynamics took place in the Late Ordovician, which caused depositional centres to shift markedly. This change was the result of the first phase of convergent deformation associated with the $\sim 450$ 300 Ma Alice Springs Orogeny (Bradshaw \& Evans, 1988; Lindsay \& Korsch, 1991; Shaw, 1991). Late Ordovician sedimentation in the Amadeus Basin is represented by mixed fluviatile and marine clastic rocks of the Carmichael Sandstone, which appears to be thickest in the south, contrasting with the underlying Cambro-Ordovician succession, which is thickest in the north (Shaw, 1991). The Ethabuka Sandstone of the Georgina Basin was deposited at a similar time (Shergold et al., 1991), and appears to be part of the same syn-orogenic package, sourced from uplifted areas between the Amadeus and Georgina basins (Haines et al., 2001). This succession was not sampled, but the ages of zircon in the syn-orogenic packages of Successions 8 and 9 constrain the amount of basin uplift and basement exhumation that took place before the deposition of Succession 7.

\section{Succession 8 (Silurian to Early Devonian - 435-405 Ma)}

Quartz arenites of the Mereenie Sandstone constitute Succession 8 in the Amadeus Basin (Wells et al., 1970). The sandstone is considered to be dominantly aeolian, with a minor fluvial component (Walley et al., 1991), and was considered by Wells et al. (1970) to be sourced from areas to the east, based on the presence of coarser detritus in the eastern part of the basin. It conformably overlies the Carmichael Sandstone in the west but lies unconformably above older units in the northeast, reflecting differential uplift associated with the $\sim 450 \mathrm{Ma}$ Rodingan Movement. The age of the Mereenie Sandstone is not well constrained, with no unequivocal biostratigraphic control, but Li et al. (1991) considered it to be mostly Silurian based on palaeomagnetic data. Although some workers considered that the Mereenie Sandstone was deposited during a relatively stable period (e.g. Jones, 1991; Nicoll et al., 1991; Shaw et al., 1992), Haines et al. (2001) noted that ${ }^{40} \mathrm{Ar}-{ }^{39} \mathrm{Ar}$ hornblende and $\mathrm{U}-\mathrm{Pb}$ titanite cooling ages from the eastern Arunta Inlier imply that it was being exhumed at this time. Thus they considered that accumulation of this thick (up to $1.5 \mathrm{~km}$ ) nonmarine package was likely to have resulted from tectonically driven subsidence generated during earliest phases of the 450-300 Ma Alice Springs Orogeny. There is no preserved record of sedimentation from this period in the Georgina Basin.

Mereenie Sandstone-Amadeus Basin ( 435-405 Ma) - Sample ANU01-357

The Mereenie Sandstone was sampled from Ellery Creek (Fig. 6, GR 304800 7364200), where it consists of a finegrained, well-sorted quartz sandstone with trough crossbed sets up to $15 \mathrm{~m}$ thick. The sandstone yielded relatively small $(\sim 50-100 \mu \mathrm{m})$, rounded zircon grains, with the results of 59 analyses listed in Table S12. The zircon grains are dominated by ages between $\sim 0.63$ and $\sim 0.49 \mathrm{Ga}$ ( $\sim 60 \%$ ), with peaks at $\sim 570$ and $\sim 495 \mathrm{Ma}$, and includes a range of higher ages, including a smaller grouping at $\sim 1.67-1.60 \mathrm{Ga}(\sim 9 \%)$ (Fig. 9a). The age spectrum is similar to that of the Stairway Sandstone, but with proportionately fewer Grenvillian ages and more ages between 0.6 and $0.5 \mathrm{Ga}$. The similarity between the detrital zircon age signatures of these two formations might reflect reworking of the underlying Cambro-Ordovician succession as a result of uplift in the northeastern part of the basin during the $\sim 450 \mathrm{Ma}$ Rodingan Movement. This interpretation is consistent with that of Wells et al. (1970), who suggested a sedimentary source based on the presence of abraded diagenetic overgrowths and the well-rounded, but poorly sorted nature of some sandstone units. Reworked Ordovician conodonts noted by Shergold et al. (1991) also support this interpretation. Because the provenance of the sandstone is essentially the same as that of the underlying Cambro-Ordovician sedimentary rocks and there are no grains younger than $\sim 0.49 \mathrm{Ga}$, the detrital zircon data are unable to more precisely constrain the depositional age of this unit.

\section{Succession 9 (Early Devonian to Carboniferous - 400-360 Ma)}

The Pertnjara Group of the Amadeus Basin unconformably overlies the Mereenie Sandstone and consists of an upward-coarsening succession of lacustrine, fluvial and alluvial fan deposits that thickened northwards towards the Alice Springs Orogen along the northern margin of the basin. The development of this succession is linked with the Early to Middle Devonian Pertnjara Movement, which uplifted and exposed the Mereenie Sandstone and created accommodation space by thrust loading (Jones, 1991; Haines et al., 2001). The subsequent Frasnian Henbury Movement and the late Frasnian to early Famennian Brewer Movement caused further uplift and influxes of coarse sediment. Correlatives of the Pertnjara Group in the southwestern Georgina Basin include the nonmarine Dulcie Sandstone and Ethabuka Sandstone, which were deposited in the Dulcie and Toko syncline areas, respectively.

\section{Upper Dulcie Sandstone-Georgina Basin ( 365 Ma) - Sample 2002080035}

The Dulcie Sandstone is a syn-orogenic clastic sedimentary unit interpreted to have been sourced from the uplifted Alice Springs Orogen to the south (Haines et al., 2001). The unit has been subdivided into a lower clay-cemented unit of probable Early Devonian (PragianEmsian) age, and an upper, escarpment-forming, silicacemented unit of Late Devonian (Frasnian) age (Freeman, 1986; Young, 1996). The upper unit was sampled at Oomoolmilla Springs, at the southern margin of the Dulcie Syncline (Fig. 7, GR 585064 7497487) where it 
consists of a well-sorted, medium- to thickly bedded nonmarine quartz sandstone, with cross-bedding and unidentified paired trackways that resemble the Devonian Beaconichnus (Gevers et al., 1971; Gevers, 1973) - K. Campbell - ANU (personal communication).

Sixty-seven detrital zircon $\mathrm{U}-\mathrm{Pb}$ isotopic analyses are listed in Table S13. The detrital zircon age spectrum has a large proportion of $0.65-0.55 \mathrm{Ga}$ ages $(\sim 30 \%)$, with peaks at $\sim 575$ and $\sim 510 \mathrm{Ma}$, and $\sim 475 \mathrm{Ma}$ (Fig. $9 \mathrm{i}$ ). There is also a significant Grenvillian-age grouping ( $\sim 27 \%)$ with peaks at $\sim 1170$ and $\sim 1125 \mathrm{Ma}$, and a range of Meso- to Palaeoproterozoic ages. This pattern is similar to that of the Stairway Sandstone suggesting that, like the Mereenie Sandstone, the Dulcie Sandstone consists of reworked Cambro-Ordovician sedimentary rocks.

In addition to the characteristic 'Cambro-Ordovician' detrital signature, there is a younger cluster of ages at $\sim 405 \mathrm{Ma}$. Although there is no known magmatism of this age in central Australia, derivation from more distal source seems unlikely given the restricted extent of syn-orogenic sedimentation. The $\sim 405 \mathrm{Ma}$ zircon consists of rounded and pitted grains with oscillatory zoning and aspect ratios of $\sim 3$. These features suggest that they are likely to have been transported by sedimentary processes from a felsic intrusive source rather than be wind-transported volcanic grains from a distant eruption. One possibility is that the zircon was derived from as yet unidentified magmatism associated with the earliest stages of the Alice Springs Orogeny, perhaps similar to younger $387 \pm 4$ Ma felsic magmatism represented by a small granitic body in the Harts Range Metamorphic Complex (Buick et al., 2001a).

\section{DISCUSSION}

The results of this study are consistent with other provenance data from the Amadeus Basin (Zhao et al., 1992; Barovich \& Foden, 2000; Camacho et al., 2002; Buick et al., 2005), but the systematic sampling reveals detail about changing sedimentation patterns, providing additional information on the timing and character of tectonism in the region. Significant changes in detrital signature coincide with periods of tectonism outside the basin and subsidence within the Centralian superbasin. The first significant change in provenance occurs between Successions 2 and 3 (i.e. between $\sim 650$ and $\sim 580 \mathrm{Ma}$ ). Late Mesoproterozoic to early Neoproterozoic zircon $(1.1-0.8 \mathrm{Ga})$ is absent from the Heavitree Quartzite and Limbla Member of the Aralka Formation (Successions 1 and 2), but present in both the Cyclops Member and Grant Bluff formations (Succession 3) (Fig. 10). If the Aralka Formation was deposited at $\sim 0.65 \mathrm{Ga}$, this would indicate that either 1.1-0.8 Ga sources were uplifted between $\sim 0.65 \mathrm{Ga}$ and $\sim 0.58 \mathrm{Ga}$ or sediments were sourced from significantly different areas after $\sim 0.65 \mathrm{Ga}$.

The close similarity between the detrital signatures and sedimentology of the late Neoproterozoic sediments of Succession 3 in the Amadeus and Georgina basins sug- gests that the basins were contiguous at this time. The marked increase in the proportion of Grenvillian-age zircon between the late Neoproterozoic and Early Cambrian of the Amadeus Basin reflects the uplift of the Musgrave Inlier during the Petermann Orogeny between 570 and $530 \mathrm{Ma}$ (Maboko et al., 1991; Camacho et al., 1997), which shed large volumes of sediment to the north and northeast (Lindsay, 1987). This 'Musgrave signature' extends well beyond the areas adjacent to the Petermann Orogen, and remains the major sediment source in the northeastern part of the Amadeus Basin, more than $400 \mathrm{~km}$ distant. The markedly different detrital zircon age spectra of the Early Cambrian Arumbera Sandstone of the Amadeus Basin and the broadly coeval Mount Baldwin Formation of the Georgina Basin might reflect the existence of a barrier to sedimentation between the two basins at this time. Such a barrier would be unlikely to be the result of basement uplift given the paucity of Arunta Inlieraged ( $\sim 1.9-1.7 \mathrm{Ga}$ ) zircon in these sediments, but might instead reflect subsidence and the creation of a depocentre across which sediment was unable to be transported. Such subsidence might be related to the development of other deeper sub-basins which formed along the northern margin of the Amadeus Basin at this time (Lindsay, 1987; Shaw, 1991).

There was a pronounced change in provenance towards the end of the Cambrian between Successions 5 and 6 , when $0.65-0.50 \mathrm{Ga}$ zircon grains began to dominate over Grenvillian-age zircon grains (Fig. 10). With the exception of the Arrinthrunga Formation, Arunta Inlier-aged zircon $(\sim 1.9-1.7 \mathrm{Ga})$ is a minor component in Late Cambrian to Early Ordovician sediments. The detrital zircon signatures of these sedimentary rocks are remarkably similar to those of contemporaneous sedimentary rocks of the Lachlan Fold Belt in southeastern Australia (Williams \& Chappell, 1998; Williams etal., 2002). This detrital signature is a characteristic feature of sedimentary rocks along the Palaeozoic Pacific Gondwana margin, with strikingly similar patterns evident in sediments from southern Australia, New Zealand, the Transantarctic Mountains and South Africa (Fig. 11; Ireland, 1992; Armstrong et al., 1998; Ireland \& Gibson, 1998; Ireland et al., 1998; Goodge et al., 2002, 2004a, b; Williams et al., 2002). The consistency of this detrital signature over several thousand kilometres implies that this zircon was derived from a common, distal source. Veevers (2000) and Ireland et al. (1998) considered the Ross-Delamerian and Beardmore orogens to be the source of $0.65-0.50 \mathrm{Ga}$ zircon, while Williams et al. (2002) argued for an even more distal source in the Mozambique Belt of the East African Orogen. Squire et al. (2006) also considered the East African Orogen to be the source of this zircon, suggesting that large-scale fan systems distributed sediment derived from the orogen across a large area of Gondwana. The consistent presence of subsidiary populations of Grenvillian-age zircon suggests that magmatism of this age occurred in the same source region as the 0.65 $0.50 \mathrm{Ga}$ zircon or that the sediment incorporated Grenvillian-age zircon at an early point during its transportation. 


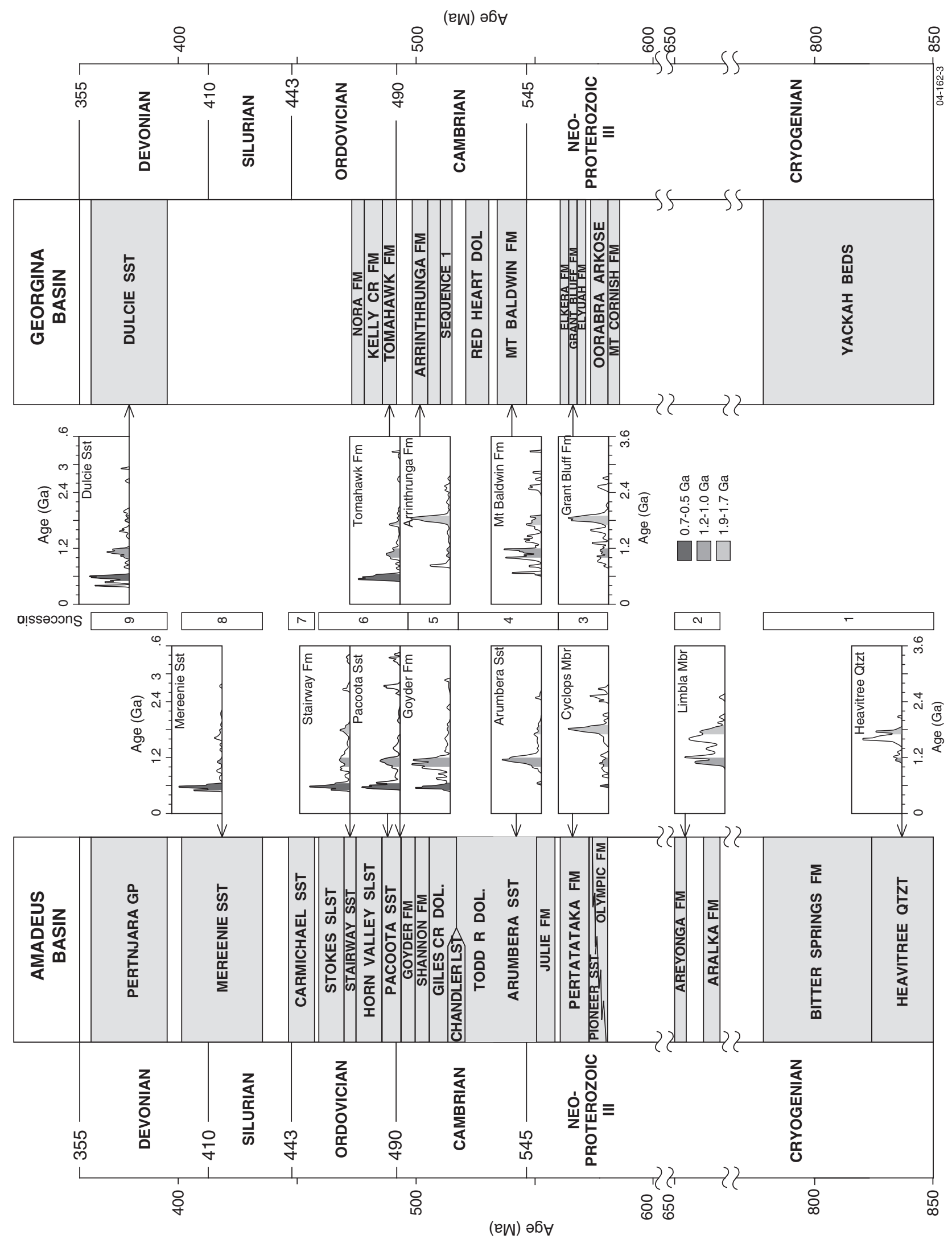

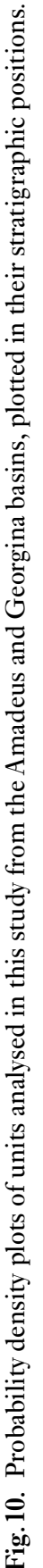




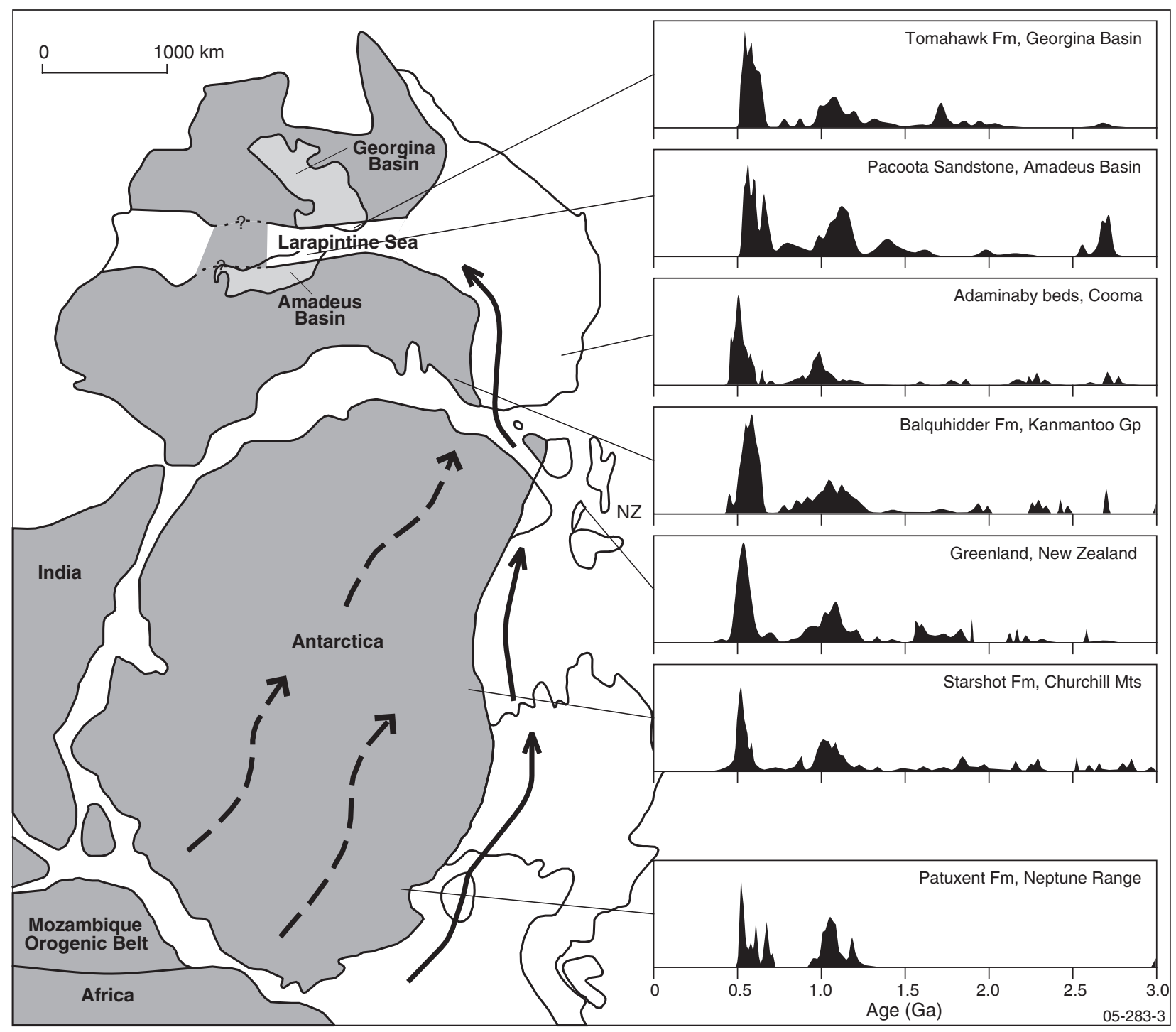

Fig. 11. Palaeogeographic reconstruction of Australia in Gondwana during the Cambro-Ordovician (based on Veevers, 2000; Li \& Powell, 2001) showing the similarity between the detrital zircon age spectra of Cambrian and Ordovician sedimentary rocks along the Pacific Gondwana margin. The near identical signature of Cambro-Ordovician sedimentary rocks in central Australia is apparently related to the development of the Larapintine Sea. The ultimate source of this sediment might have been east Antarctica or the Mozambique Orogenic Belt of east Africa. Black arrows indicate possible sediment transport paths. Data from this study, Ireland et al. (1998), Williams (2001), Goodge et al. (2004b).

The Grenvillian ages appear to lack the $\sim 1.07 \mathrm{Ga}$ component characteristic of the Musgrave Inlier, but more data of higher precision would need to be collected to resolve potential differences between the 'Musgrave' and 'Pacific Gondwana' Grenvillian populations.

The close similarity between the detrital signatures of the Centralian Superbasin sediments and those of the Pacific Gondwana margin suggests a common source and a linkage between the two sedimentary systems at that time. The influx of 'Pacific Gondwana' zircon in central Australia coincides with the transgression of the Larapintine Sea during the latest Cambrian to early Ordovician and the onset of deeper water conditions (Fig. 11; Webby, 1978; Walley et al., 1991). Although fluvial fan systems might have been important in the transportation of detritus away from the East African Orogen, as suggested by Squire et al. (2006),
Cambro-Ordovician sedimentary rocks do not occur to the south of the Amadeus Basin, but are restricted to the eastern margin of the continent. This suggests that the transportation of sediment into central Australia did not take place by fluvial processes transporting detritus directly from the East African Orogen, but rather via a marine linkage along the eastern margin of Gondwana.

As the Larapintine Sea developed, there was a switch in palaeocurrent directions, with a change from generally easterly palaeocurrents in Cambrian fluvial and marine sedimentary rocks to west- to northwesterly palaeocurrents in Early Ordovician marine rocks (Fig. 12; Wells et al., 1970; Cook, 1972; Deckelman et al., 1993). Palaeocurrent data for the early Ordovician Stairway Sandstone, which in several places has current directions parallel to isopachs, indicates that sediment was transported largely 

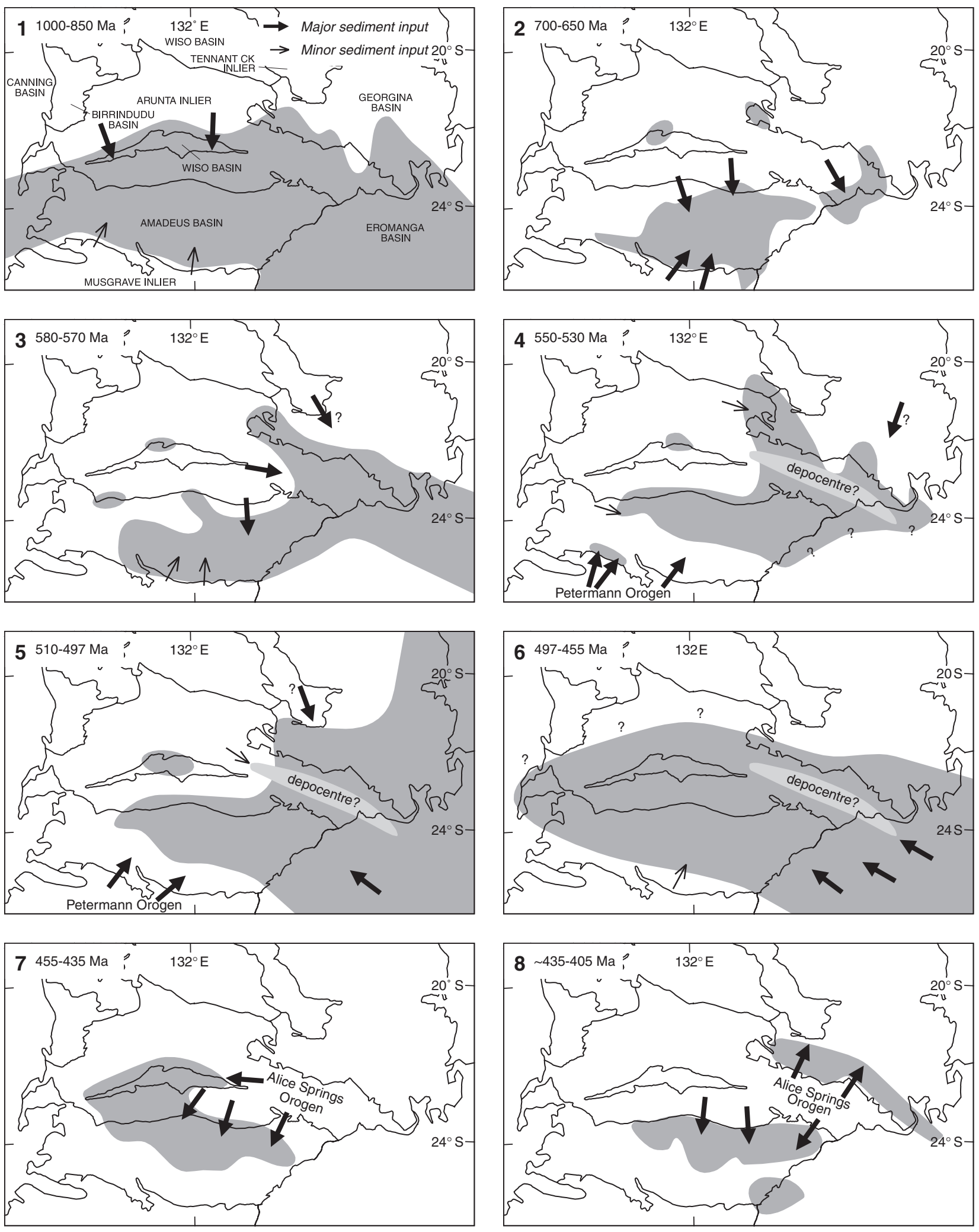

Fig. 12. Changing patterns of sedimentation in the Amadeus and Georgina basins for Successions 1-8, with inferred sediment sources reflecting the effects of local uplift and subsidence.

by westwards longshore movement (Cook, 1972). Palaeogeographic reconstructions indicate that the Pacific Gondwanan margin during the Early Ordovician was oriented approximately parallel to the equator at a latitude of $\sim 15^{\circ} \mathrm{N}$ (e.g. Li \& Powell, 2001). In this orientation, the north equatorial current might have been an effective mechanism for dispersing sediment along the Pacific Gondwana margin from sources in Africa and/or the 
Transantarctic Mountains (Fig. 11), before being transported into central Australia along the margin of the Larapintine Sea.

The absence of a 'Pacific Gondwana' zircon signature in the latest Cambrian Arrinthrunga Formation might be due to slower subsidence of the northern margin of the Larapintine Sea relative to the southern margin. The Arrinthrunga Formation is dominated by peritidal carbonates (Kruse et al., 2002), with minor siliciclastic input and consequently little zircon, while the equivalent lower Goyder Formation in the Amadeus Basin occurs at the top of an upwards-deepening succession with a significantly greater siliciclastic component (Kennard \& Lindsay, 1991). The relative prominence of Grenvillian-age zircon in the Goyder Formation suggests that sediment might have derived from both the Musgrave Inlier and the Pacific Gondwana margin, implying that the Larapintine Sea was in its earliest stages of formation during the Late Cambrian, before strong northwesterly marine currents completely dominated sediment transportation patterns.

The lack of Arunta Inlier-age zircon in sediments deposited within the Larapintine Sea indicates that there was little or no topography in central Australia during the Early Ordovician, with much of the Arunta Inlier buried beneath the Centralian Superbasin. Isopachs for Early Ordovician sedimentary rocks in the Amadeus and Georgina basins increase toward the now exhumed Harts Range region between the two basins, implying that the area was a depocentre (Hand et al., 1999; Mawby et al., 1999). Upper amphibolite- to granulite-facies metamorphism of the 475-460 Ma Larapinta Event took place beneath this depocentre in the Harts Range region, resulting in the development of a pervasive flat-lying fabric in the middle to lower crust, with no large-scale folding of the metasedimentary sequence (Hand et al., 1999; Mawby et al., 1999). These constraints are consistent with an extensional rather than convergent setting for the metamorphism, which was coincident with the onset of rifting in the Canning Basin to the northwest (Romine et al., 1994). The heat source for this metamorphism appears to be a result of crustal thinning and emplacement of tholeiitic mafic magmas, which are common in the Harts Range, but absent in the adjacent Cambro-Ordovician successions of the Amadeus and Georgina basins.

Episodic convergent deformation during the Alice Springs Orogeny between $\sim 450$ and $\sim 300$ Ma caused uplift of the northeastern Amadeus and southwestern Georgina basins and exhumation of basement in the Harts Range region. This uplift resulted in the deposition of unconformity-bound packages of clastic sediments in relatively narrow foreland basins adjacent to the uplifted areas. The detrital zircon signatures of the Mereenie and Dulcie sandstones are similar to those of underlying latest Cambrian to Early Ordovician sedimentary rocks and are interpreted to have been sourced from these successions as they were uplifted. The paucity of Arunta-age zircon in these units indicates that erosion did not exposed rocks older than about Late Cambrian age. The maximum thick- ness of the Ordovician succession in the Amadeus Basin is $\sim 1800 \mathrm{~m}$ (Lindsay, 1993), indicating that the Amadeus Basin was uplifted by less than $\sim 2 \mathrm{~km}$ before $\sim 365 \mathrm{Ma}$, when the Dulcie Sandstone was deposited. In the Harts Range area, the Ordovician succession is interpreted to be significantly thicker than that preserved in the Amadeus or Georgina basins (Hand et al., 1999; Buick et al., 2005), which allows for a much greater degree of basement exhumation in this area. The major phase of basement exhumation and exposure thus appears to have taken place during the $\sim 330 \mathrm{Ma}$ Mount Eclipse Movement of the Alice Springs Orogeny.

\section{CONCLUSIONS}

For much of the Neoproterozoic, sediments appear to have been largely sourced from the Arunta Inlier, and to a lesser degree the Musgrave Inlier, which appears to have been at least partially exposed at this time. Uplift of the Musgrave Inlier during the Petermann Orogeny between $\sim 0.56$ and $\sim 0.53 \mathrm{Ga}$ provided a dominant sediment source for the Amadeus Basin, while in the Georgina Basin sediments were derived from distant areas to the northeast. The change in detrital signature during the Early Cambrian is interpreted to reflect the initial stages of rifting between the Georgina and Amadeus basins, and the formation of deeper NW-trending sub-basins, which formed a barrier to sediment transfer. Towards the end of the Cambrian, the nature of sedimentation changed dramatically with the influx of sediment sourced from the Pacific Gondwanan margin. The formation of the epicratonic Larapintine Sea marks the peak of transgression and input of 'Pacific Gondwana' sediment. The primary source of this sediment is possibly east Antarctica or the Mozambique Belt of the East African Orogen, implying a sediment transport of several thousand kilometres. Granulite-facies metamorphism beneath the Larapintine Sea during the Early Ordovician is constrained by the detrital zircon signature of overlying sediments to have occurred without significant positive topographic expression, consistent with extensional or transtensional tectonism.

The northeastern Amadeus Basin and southwestern Georgina Basin were uplifted during the mid-Ordovician and Devonian as part of the 450-300 Ma Alice Springs Orogeny, reworking Cambro-Ordovician sedimentary rocks. The main phase of basement exhumation between the two basins appears to have occurred at $\sim 330 \mathrm{Ma}$ towards the end of the Alice Springs Orogeny.

\section{ACKNOWLEDGEMENTS}

Russell Korsch (Geoscience Australia) and Charlotte Allen (Australian National University) are thanked for providing samples of the Limbla Member and the Stairway Sandstone, respectively. J. Lindsay, R. Rainbird, R. Korsch and $\mathrm{K}$. Sircombe provided constructive reviews on the 
manuscript. This work was carried out as part of a $\mathrm{PhD}$ study at the Australian National University.

\section{Supplementary material}

The following supplementary material for this article is available for this article:

Table S1. SHRIMP U-Th-Pb isotopic analyses of zircon from the Heavitree Quartzite, Amadeus Basin.

Table S2. SHRIMP U-Th-Pb isotopic analyses of zircon from the Limbla Member, Amadeus Basin.

Table S3. SHRIMP U-Th-Pb isotopic analyses of zircon from the Cyclops Member, Amadeus Basin.

Table S4. SHRIMP U-Th-Pb isotopic analyses of zircon from the Grant Bluff Formation, Georgina Basin.

Table S5. SHRIMP U-Th-Pb isotopic analyses of zircon from the Arumbera Sandstone (IV), Amadeus Basin.

Table S6. SHRIMP U-Th-Pb isotopic analyses of zircon from the Mount Baldwin Formation, Georgina Basin.

Table S7. SHRIMP U-Th-Pb isotopic analyses of zircon from the Goyder Formation, Amadeus Basin.

Table S8. SHRIMP U-Th-Pb isotopic analyses of zircon from the Arrinthrunga Formation, Georgina Basin.

Table S9. SHRIMP U-Th-Pb isotopic analyses of zircon from the Pacoota Sandstone, Amadeus Basin.

Table S10. SHRIMP U-Th-Pb isotopic analyses of zircon from the Tomahawk Formation, Georgina Basin.

Table S11. SHRIMP U-Th-Pb isotopic analyses of zircon from the Stairway Sandstone, Amadeus Basin.

Table S12. SHRIMP U-Th-Pb isotopic analyses of zircon from the Mereenie Sandstone, Amadeus Basin.

Table S13. SHRIMP U-Th-Pb isotopic analyses of zircon from the Dulcie Sandstone, Georgina Basin.

This material is available as part of the online article from: http://www.blackwell-synergy.com/doi/abs/10.1111/ j.1365-2117.2007.00326.x (This link will take you to the article abstract).

Please note: Blackwell Publishing are not responsible for the content or functionality of any supplementary materials supplied by the authors. Any queries (other than missing material) should be directed to the corresponding author for the article.

\section{REFERENCES}

Armstrong, R.A., De Wit, M.J., Reid, D., York, D. \& ZartMAN, R. (1998) Cape Town's Table Mountain reveals rapid Pan African uplift of its basement rocks. F. Afr. Earth Sci., 27, 10-11.

Barovich, K.M. \& Foden, J. (2000) Nd isotope constraints on sources of Palaeozoic petroleum bearing rocks in the Amadeus Basin, central Australia. Geol. Soc. Aust., Abstr., 59, 22.

BLACK, L.P. \& SHAW, R.D. (1992) U-Pb zircon geochronology of prograde Proterozoic events in the Central and Southern Provinces of the Arunta Block, central Australia. Aust. F. Earth Sci., 39, 153-171.

Black, L.P. \& SHaw, R.D. (1995) An assessment, based on U-Pb zircon data, of $\mathrm{Rb}-\mathrm{Sr}$ dating in the Arunta Inlier, central Australia. Precamb. Res., 71, 31-15.
Blair, T.C. \& Bilodeau, W.L. (1988) Development of tectonic cyclothems in rift, pull-apart and foreland basins: sedimentary response to episodic tectonism. Geology, 16, 517-520.

Bowring, S., Myrow, P., Landing, E., Ramezani, J. \& GrotZINGER, J. (2003) Geochronological constraints on terminal Neoproterozoic events and the rise of metazoans. Geophys. Res. Abstr. 5, 213-219.

Bozhкov, N.A. (1986) The evolution of the mobile zones of Gondwana and Laurasia in the late Precambrian. Tectonophysics, 126, 125-135.

Bradshaw, J.D. \& Evans, P.R. (1988) Palaeozoic tectonics, Amadeus Basin, central Australia. APEA7., 28, 267-282.

Buick, I.S., Hand, M., Williams, I.S., Mawby, J., Miller, J.A. \& NiCOLL, R.S. (2005) Detrital zircon provenance constraints on the evolution of the Harts Range Metamorphic Complex (central Australia): links to the Centralian Superbasin. 7. Geol. Soc. London, 162, 777-787.

Buick, I.S., Miller, J.A., Williams, I.S. \& Cartwright, I. (2001a) Ordovician high-grade metamorphism of a newly recognised late Neoproterozoic terrane in the northern Harts Range, central Australia. 7. Metamorph. Geol., 19, 373-394.

Buick, I.S., Miller, J.A., Williams, I.S., Hand, M. \& Mawby, J. (2001b) Deep holes in the Centralian Superbasin, SHRIMP zircon constraints on the depositional age of granulites in the eastern Arunta Block. Geol. Soc. Aus., Abstr., 64, 13-14.

Calver, C.R., Black, L.P., Everard, J.L. \& Seymour, D.B. (2004) U-Pb zircon age constraints on late Neoproterozoic glaciation in Tasmania. Geology, 32, 893-896.

Camacho, A., Compston, W., McCulloch, M. \& McDouGALL, I. (1997) Timing and exhumation of eclogite facies shear zones, Musgrave Block, central Australia. 7. Metamorph. Geol., $15,735-751$.

Camacho, A., Hensen, B.J. \& Armstrong, R. (2002) Isotopic test of a thermally driven intraplate orogenic model, Australia. Geology, 30, 887-890.

Camacho, A., Simons, B. \& Schmidt, P.W. (1991) Geological and palaeomagnetic significance of the Kulgera Dyke Swarm, Musgrave Block, NT, Australia. Geophys. F. Int., 107, $37-45$.

Cas, R.A.F. \& Wright, J.V. (1988) Volcanic Successions, Modern and Ancient. Chapman \& Hall, London.

Claoué-Long, J., Fraser, G., Huston, D., Neumann, N. \& Worden, K. (2005) Towards a correlation of the earliest Proterozoic evolution in central Australia Annual Geoscience Exploration Seminar (AGES) 2005 Record of Abstracts. Northern Territory Geological Survey Record 2005-01.

Claoué-Long, J.C., Compston, W., Roberts, J. \& Fanning, C.M. (1995) Two Carboniferous ages: a comparison of SHRIMP zircon dating with conventional zircon ages and ${ }^{40} \mathrm{Ar} /{ }^{39} \mathrm{Ar}$ analysis. In: Geochronology Times Scales and Global Stratigraphic Correlation (Ed. by W.A. Berggren, D.V. Kent, M.-P. Aubrey \& J. Hardenbol), SEPM Spec. Pub., 54, 3-21.

Claoué-Long, J.C. \& Hoatson, D. (2005) Proterozoic maficultramafic intrusions in the Arunta Region, central Australia: Part 2: event chronology and regional correlations. Precamb. Res., 142, 134-158.

Close, D., Scrimgeour, I. \& Edgoose, C. (2003b) Compilation of geochronological data from the northwestern Musgrave Block, NT. Northern Territory Geological survey, Technical Report 2003-2005. 
Close, D., Scrimgeour, I., Edgoose, C., Cross, A., ClaouéLong, J.C., Kinny, P. \& Meixner, T. (2003a) Redefining the Warumpi Province. Annual Geoscience Exploration Seminar (AGES) 2003 record of Abstracts, Northern Territory Geological Survey Record 2003-001.

Cloose, D.F., Edgoose, C.J. \& Scrimgeour, I.R. (2005) The Tjauwata Group: a late Mesoproterozoic rift succession underlying the southwestern Amadeus Basin. Central Australian Basins Symposium (CABS), Abstracts (pp. 39-40). Northern Territory Geological Survey, Darwin.

Collins, W.J. \& Shaw, R.D. (1995) Geochronological constraints on orogenic events in the Arunta Inlier: a review. Precamb. Res., 71, 315-346.

Compston, D.M. (1995) Time constraints on the evolution of the Tennant Creek Block, northern Australia. Precamb. Res., 71, 107-129.

Cook, P.J. (1972) Sedimentological studies on the Stairway Sandstone of central Australia. Bureau Mineral Resources, Aust. Bull., 95, 73pp

Corfu, F., Hanchar, J.M., Hoskin, P.W.O. \& Kinny, P. (2003) Atlas of zircon textures. In: Zircon (Ed. by J.M. Hanchar \& P.W.O. Hoskin), Rev. Mineral. Geochem., 53, 468-500.

Cross, A., Claoué-Long, J.C. \& Crispe, A.J. (2003) Summary of results. Joint NTGS-GA geochronlogy project: Tanami Region 2001-2002. Northern Territory Geological Survey Record 2003-006.

Cross, A. \& Crispe, A.J. (2007) SHRIMP U-Pb analyses of detrital zircon: a window to understanding the Palaeoproterozoic development of the Tanami Region, Northern Australia. Miner. Deposita, 42, 27-50.

Daly, S.J., Fanning, C.M. \& Fairclough, M.C. (1998) Tectonic evolution and exploration potential of the Gawler Craton, South Australia. AGSO 7. Aust. Geol. Geophys., 17, $145-168$.

Deckelman, J.A. (1991) Recognition of a fluvial facies in the Pacoota Sandstone and its implications for petroleum exploration. Bureau Mineral Resources, Aust. Bull., 236, 285-301.

Deckelman, J.A., Gorter, J.D. \& Lindsay, J.F. (1993) Pacoota sandstone of the Amadeus Basin. In: Geological Atlas of the Amadeus Basin (Ed. by J.F. Lindsay) Australian Government Publishing Service, Canberra.

DeGraaff-Surpless, K., Graham, S.A., Wooden, J.L. \& McWilliams, M.O. (2002) Detrital zircon provenance analysis of the Great Valley Group, California: evolution of an arcforearc system. Geol. Soc. Am. Bull., 114, 1564-1580.

Doutch, H.F. \& Nicholas, E. (1978) The Phanerozoic sedimentary basins of Australia and their tectonic implications. Tectonophysics, 48, 365-388.

Dunlap, W.J., Teyssier, C., Mc Dougall, I. \& Baldwin, S. (1995) Thermal and structural evolution of the intracratonic Arltunga Nappe Complex, central Australia. Tectonics, 14, 11821204.

DunPhy, J.M. \& MCNaughton, N.J. (1998) Geochronology of the Telfer granitoids: zircon and titanite U-Pb SHRIMP data. Geol. Soc. Aust. Abstr., 49, 127.

Eyre, B. (1994) Early Cambrian alluvial fan-deltas in the Georgina Basin, Australia. Aust. 7. Earth Sci., 41, 27-36.

Fanning, C.M., Ludwig, K.R., Forbes, B.G. \& Preiss, W.V. (1986) Single and multiple grain U-Pb zircon analyses for the early Adelaidean Rook Tuff, Willouran Ranges, South Australia. Geol. Soc. Aust. Abstr., 15, 71-72.

Fergusson, C.L., Carr, P.F., Fanning, C.M. \& Green, T.J. (2001) Proterozoic-Cambrian detrital zircon and monazite ages from the Anakie Inlier, central Queensland: Grenville and Pacific-Gondwana signatures. Aust. 7. Earth Sci., 48, $857-866$.

Forman, D.J. (1971) The Arltunga nappe complex, MacDonnell Ranges, Northern Territory, Australia. 7. Geol. Soc. Aust., 18, 173-182.

Freeman, M.J. (1986) Huckitta, Northern Territory, (Second Edition), 1:250 000 geological map series explanatory notes, SF 53-11 Northern Territory Geological Survey, Darwin.

Gevers, T.W. (1973) A new name for the ichnogenus Arthropodicus Gevers 1971. F. Paleontol., 47, 1002.

Gevers, T.W, Frakes, L.A., Edwards, L.N. \& Marzolf, J.E. (1971) Trace fossils in the Lower Beacon sediments (Devonian), Darwin Mountains, South Victoria Land, Antarctica. 7. Paleontol., 45, 81-94.

Glass, L.M. \& Phillips, D. (2006) The Kalkarindji continental flood basalt province: a new Cambrian large igneous province in Australia with possible links to faunal extinctions. Geology, 34, 461-464.

Glikson, A.Y., Stewart, A.J., Ballhaus, C.G., Clarke, G.L., Feeken, E.H.J., Leven, J.H., Sheraton, J.W. \& Sun, S-S. (1996) Geology of the western Musgrave Block, central Australia, with particular reference to the mafic-ultramafic Giles Complex. Aust. Geol. Surv. Org. Bull., 239.

Goodge, J.W., Myrow, P., Phillips, D., Fanning, C.M. \& Williams, I.S. (2004a) Siliciclastic record of rapid denudation in response to convergent margin orogenesis, Ross Orogen, Antarctica. In: Detrital Thermochronology; Provenance Analysis, Exhumation, and Landscape Evolution of Mountain Belts (Ed. by B. Matthias \& C. Spiegel), Geol. Soc. Am. Special Paper 378, $105-126$.

Goodge, J.W., Myrow, P., Williams, I.S. \& Bowring, S.A. (2002) Age and provenance of the Beardmore Group, Antarctica: constraints on Rodinia supercontinent breakup. 7. Geol., $110,393-406$.

Goodge, J.W., Williams, I.S. \& Myrow, P. (2004b) Provenance of Neoproterozoic and lower Palaeozoic siliciclastic rocks of the central Ross Orogen, Antarctica: detrital record of rift-, passive- and active-margin sedimentation. Geol. Soc. Am. Bull., $116,1253-1279$.

Gorter, J.D. (1984) Source rock potential of the Horn Valley Siltstone, Amadeus Basin. APEA F., 24, 66-90.

Haines, P.W. (2005) Contrasting Ordovician depositional histories and petroleum systems of the Canning and Amadeus basins: rethinking the Larapinta Seaway concept. Central Australian Basins Symposium (CABS), Abstracts. Northern Territory Geological Survey, Darwin.

Haines, P.W., Hand, M. \& Sandiford, M. (2001) Palaeozoic synorogenic sedimentation in central and northern Australia: a review of distribution and timing with implications for the evolution of intracontinental orogens. Aust. 7. Earth Sci., 48, 911-928.

Hand, M., Mawby, J., KInny, P. \& Foden, J. (1999) U-Pb ages from the Harts Range, central Australia: evidence for early Ordovician extension and constraints on Carboniferous metamorphism. 7. Geol. Soc. London, 156, 715-730.

Hoffman, P.F., Kaufman, A.J., Halverson, G.P. \& Schrag, D.P. (1998) A Neoproterozoic snowball Earth. Science, 281, 1342-1346.

Hutton, L.J., Fanning, C.J. \& Withnall, I.J. (1998) The Cape River area; evidence for late Mesoproterozoic and Neoprtoerozoic to Cambrian crust in north Queensland. Geol. Soc. Aust. Abstr., 49, 216. 
IRELAND, T.R. (1992) Crustal evolution of New Zealand: evidence from age distributions of detrital zircons in Western Province paragneisses and Torlesse greywacke. Geochim. Cosmochim. Acta., 56, 911-920.

Ireland, T.R., Flöttmann, T., Fanning, C.M., Gibson, G.M. \& Preiss, W.V. (1998) Development of the early Paleozoic Pacific margin of Gondwana from detrital-zircon ages across the Delamerian orogen. Geology, 26, 243-246.

IRELAND, T.R. \& GiBSON, G.M. (1998) SHRIMP monazite and zircon geochronology of high-grade metamorphism in New Zealand. 7. Metamorph. Geol., 16, 149-167.

Jackson, K.S., McKirdy, D.M. \& Deckelman, J.A. (1984) Hydrocarbon generation in the Amadeus Basin. APEA 7., 24, $42-65$.

Jenkins, R.J.F., McKirdy, D.M., Foster, C.B., O’Leary, T. \& Pell, S.D. (1992) The record and stratigraphic implications of organic-walled microfossils from the Ediacaran (terminal Proterozoic) of South Australia. Geol. Mag., 129, 401-410.

Jones, B.G. (1991) Fluvial and lacustrine facies in the Middle to Late Devonian Pertnjara Group, Amadeus Basin, Northern Territory, and their relationship to tectonic events and climate. Burea u Mineral Resources, Aust. Bull., 236, 333-348.

Keble, R.A. \& Benson, W.N. (1939) Graptolites of Australia. Memoirs Natl History Museum, Melbourne, 11, 11-99.

Kendall, B.S. \& Creaser, R.A. (2004) Re-Os depositional age of the Neoproterozoic Aralka Formation (Amadeus Basin, Australia) revisited. Geol. Soc. Am. Abstr. Prog., 36, 459.

Kennard, J.M. \& Lindsay, J.F. (1991) Sequence stratigraphy of the latest Proterozoic-Cambrian Pertaoorta Group, northern Amadeus Basin, central Australia. Bureau Mineral Resources, Aust. Bull., 236, 171-194.

KorsCH, R.J. \& LindSAY, J.F. 1989 Relationships between deformation and basin evolution in the intracratonic Amadeus Basin, central Australia. In: Deformation of Crustal Rocks (Ed. by A. Ord), Tectonophysics 158, 5-22.

Kruse, P.D., Brakel, A.T., Dunster, J.N. \& Duffett, M.L. (2002) Tobermory, Northern Territory, (Second Edition) 1:250 000 geological map series explanatory notes, SF 53-12. Northern Territory Geological Survey, Darwin, Geoscience Australia, Canberra.

Kruse, P.D. \& Mohammed, L.C. (2005) Geology of the southern Georgina Basin, Northern Territory, (First edition), 1:500 000 Geological Special Northern Territory Geological Survey, Darwin.

LAMBECK, K. (1983) Structure and evolution of the intracratonic basins of central Australia. Geophys. 7. Roy. Astr. Soc., 74, 843866.

Lambeck, K. (1984) Structure and evolution of the Amadeus, Officer and Ngalia basins of central Australia. Aust. 7. Earth Sci. 31, 25-48.

Li, Z.X. \& Powell, C.McA (2001) An outline of the plaeogeographic evolution of the Australasian region since the beginning of the Neoproterozoic. Earth Sci. Rev., 53, 237277.

Li, Z.X., Powell, C.McA, Embleton, B.J.J. \& Schmidt, P.W. (1991) New Palaeomagnetic results from the Amadeus Basin and their implications for stratigraphy and tectonics: Australia. Bureau Mineral Resources, Aust. Bull., 236, 349-360.

LindSAY, J.F. (1987) Sequence stratigraphy and depositional controls in Late Proterozoic-Early Cambrian sediments of Amadeus Basin, central Australia. AAPG Bull., 71, 1387-1403.

LINDSAY, J.F. (1989) Depositional controls on glacial facies associations in a basinal setting, late Proterozoic, Amadeus Basin, central Australia. Palaeogeograp. Palaeoclimatol. Palaeoecol., 73, 205-232.

LindsAY, J.F. (1993) Ordovician rocks of the Amadeus Basin. In: Geological Atlas of the Amadeus Basin (Ed. by J.F. Lindsay) Australian Geological Survey Organisation, Canberra.

Lindsay, J.F. (1999) Heavitree Quartzite, a Neoproterozoic (ca. 800-760 Ma), high-energy, tidally influenced ramp association, Amadeus Basin, central Australia. Aust. 7. Earth Sci., 46, 127-139.

Lindsay, J.F. (2002) Supersequences, superbasins, supercontinents-evidence from the Neoproterozoic-Early Palaeozoic basins of central Australia. Basin Res., 14, 207-223.

Lindsay, J.F. \& Korsch, R.J. (1989) Interplay of tectonics and sea-level changes in basin evolution: an example from the intracratonic Amadeus Basin, central Australia. Basin Res., 2, $3-25$.

Lindsay, J.F. \& Korsch, R.J. (1991) The evolution of the Amadeus Basin, central Australia. Bureau Mineral Resources, Aust. Bull., 236, 7-32.

Lindsay, J.F., Korsch, R.J. \& Wilford, J. (1987) Timing the breakup of a Proterozoic supercontinent: evidence from Australian intracratonic basins. Geology, 15, 1061-1064.

Мавоко, M.A.H., Williams, I.S. \& Compston, W. (1991) Zircon $\mathrm{U}-\mathrm{Pb}$ chronometry of the pressure and temperature history of granulites in the Musgrave Ranges, central Australia. 7. Geol., 99, 675-697.

Mahoney, J.B., Mustard, P.S., Haggart, J.W., Friedman, R.M., FAnning, C.M. \& McNicoll, N.J. (1999) Achaean zircons in Cretaceous strata of the western Canadian Cordillera: the "Baja B.C." hypothesis fails a crucial test. Geology, 27, 195198.

Mawby, J., Hand, M. \& Foden, J. (1999) Sm-Nd evidence for high-grade Ordovician metamorphism in the Arunta Block, central Australia. 7. Metamorph. Geol., 17, 653-668.

McCann, T. \& Saintot, A. (2003) Tracing tectonic deformation using the sedimentary record: an overview. In: Tracing Tectonic Deformation Using the Sedimentary Record (Ed. by T. McCann \& A. Saintot), Geol. Soc., London, Special Publ., 208, 1-28.

McIlroy, D., Jenkins, R.J.F. \& Walter, M.R. (1997) The nature of the Proterozoic-Cambrian transition in the northern Amadeus Basin, central Australia. Precamb. Res., 86, 97-113.

McQueEn, H.W.S. \& Beaumont, C. (1989) Mechanical models of tilted block basins. In: Origin and Evolution of Sedimentary Basins and their Energy and Resource Potential (Ed. by R.A. Price), Am. Geophys. Union, Geophys. Monogr., 48, 65-71.

Nelson, D.R. (1995) Compilation of SHRIMP U-Pb zircon geochronology data, 1994. Western Australia Geological Survey Record, 1995/3.

Nicoll, R.S., Gorter, J. \& Owen, M. (1991) Ordovician sediments in the Waterhouse Range Anticline, Amadeus Basin, central Australia: their interpretation and tectonic implications. Burea u Mineral Resources, Aust. Bull., 236, 277-284.

Oaks, R.Q., Deckelman, J.A., Conrad, K.T., Hamp, L.P., Phillips, J.O. \& Stewart, A.J. (1991) Sedimentation and tectonics in the northeastern and central Amadeus Basin, central Australia. Bureau Mineral Resources, Aust. Bull., 236, 73-90.

Page, R.W., Jackson, J. \& Krassay, A.A. (2000) Constraining sequence stratigraphy in north Australian basins: SHRIMP U$\mathrm{Pb}$ geochronology between Mt Isa and McArthur River. Aust. 7. Earth Sci., 47, 431-459.

Pell, S.D., Williams, I.S. \& Chivas, A.R. (1997) The use of protolith zircon-age fingerprints in determining the proto- 
source areas for some Australian dune sands. Sediment. Geol., $109,223-260$.

Rainbird, R.H., Heaman, L.M. \& Young, G.M. (1992) Sampling Laurentia; detrital zircon geochronology offers evidence for an extensive Neoproterozoic river system originating from the Grenville Orogen. Geology, 20, 351-354.

Rainbird, R.H., McNicoll, V.J., Theriault, R.J., Heaman, L.M., Аввотt, J.G., Long, D.G.F. \& Thorkelson, D.J. (1997) Pan-continental river system draining Grenville Orogen recorded by $\mathrm{U}-\mathrm{Pb}$ and $\mathrm{Sm}-\mathrm{Nd}$ geochronology of Neoproterozoic quartzarenites and mudrocks, northwestern Canada. 7. Geol., 105, 1-17.

Romine, K.K., Southgate, P.N., Kennard, J.M. \& Jackson, M.J. (1994) The Ordovicain to Silurian phase of the Canning Basin, WA: structure and sequence evolution. In: The Sedimentary Basins of Western Australia (Ed. by P.G. Purcell \& R.R. Purcell), P. Petrol. Expl. Soc. Aust. (PESA) Symp., Perth, 851-864.

Ross, G.M. \& Bowring, S.A. (1990) Detrital zircon geochronology of the Windemere Supergroup and the tectonic assembly of the southern Canadian Cordillera. 7. Geol., 98, 879-893.

Rutland, R.W.R. (1976) Orogenic evolution of Australia. Earth Sci. Rev., 12, 161-196.

SCHAEFER, B.F. \& Burgess, J.M. (2003) Re-Os isotopic age constraints on the Neoproterozoic Amadeus Basin: implications for the 'Snowball Earth' 7. Geol. Soc., London, 160, 825-828.

SCHWARZ, A. \& JAGODZINSKI, L. (2006) Recent geochronological constraints on paragneisses of the Musgrave Province. Australian Earth Sciences Convention 2006, Melbourne, Conference Abstracts, Geological Society of Australia.

Scrimgeour, I. (2003) Developing a revised framework for the Arunta Region. Annual Geoscience Exploration Seminar (AGES) 2003 record of abstracts, Northern Territory Geological Survey Record 2003-001.

SHAw, R.D. (1987) Basement uplift and basin subsidence in central Australia. Unpublished PhD Thesis, Australian National University.

SHaw, R.D. (1991) The tectonic development of the Amadeus Basin, central Australia. Bureau Mineral Resources, Aust. Bull., 236, $429-461$

Shaw, R.D., Etheridge, M.A. \& Lambeck, K. (1991) Development of the Late Proterozoic to Mid-Paleozoic, intracratonic Amadeus Basin in central Australia: a key to understanding tectonic forces in plate. Tectonics, 10, 688-721.

Shaw, R.D., Zieler, P.K., McDougall, I. \& Tingate, P. (1992) The Palaeozoic history of an unusual thrust belt in central Australia: a key to understanding tectonic forces in plate. Tectonics, 10, 688-721.

Shergold, J.H. (1986) Review of the Cambrian and Ordovician palaeontology of the Amadeus Basin, central Australia. Bureau Mineral Resources Rep., 276, 21pp.

Shergold, J.H. \& Druce, E.C. (1980) Upper Proterozoic and Lower Palaeozoic rocks of the Georgina Basin. In: The Geology and Geophysics of Northeastern Australia (Ed. by R.A. Henderson \& P.J. Stephenson), Geol. Soc. Aus., Queensland Div., Brisbane, 149-174.

Shergold, J.H., Elphinstone, R., Laurie, J.R., Nicoll, R.S., Walter, M.R., Young, G.C. \& Zang, W. (1991) Late Proterozoic and early Palaeozoic palaeontology and biostratigraphy of the Amadeus Basin. Bureau Mineral Resources, Aust. Bull., 236, 97-111.

Sircombe, K.N. \& Freeman, M.J. (1999) Provenance of detrital zircons on the western Australian coastline: implications for the geologic history of the Perth Basin and denudation of the Yilgarn Craton. Geology, 27, 879-882.

Smith, K.G. (1964) Progress report on the geology of the Huckitta 1:250 000 sheet, Northern Territory. Bureau of Mineral Resources, Australia Report, 67.

Southgate, P.N. (1991) A sedimentological model for the Loves Creek Member of the Bitter Springs Formation, northern Amadeus Basin. Bureau Mineral Resources, Geol. Geophys. Bull., 236, 113-126.

Squire, R.J., Campbell, I.H., Allen, C.M. \& Wilson, C.J. (2006) Did the Transgondwanan Supermountain trigger the explosive radiation of animals on Earth? Earth. Planet. Sci. Lett., 250, 116-133.

Steiger, R.H. \& Jäger, J.E. (1977) Subcommission on geochronology: convention on the use of decay constants in geo- and cosmochronology. Earth Planet. Sci. Lett., 36, 359-362.

Swain, G., Hand, M., Barovich, K. \& Schwarz, M. (2004) The tectonic setting of the Hiltaba Suite; magmatism and mineralisation linked to the collision of northern Australia and the Mawson continent. Geol. Soc. Aust. Abstr, 73, 189.

Tingate, P.R. (1991) Apatite fission track analysis of the Pacoota and Stairway Sandstones, Amadeus Basin, central Australia. Burea u Mineral Resources, Aust. Bull., 236, 525-540.

Towler, B.F. (1986) Reservoir simulation in the Mereenie Field. APEA7., 26, 428-446.

Veevers, J.J. (1976) Early Phanerozoic events on and alongside the Australasian-Antarctic Platform. 7. Geol. Soc. Aust., 23, 183-206.

Veevers, J.J., (Ed.). (1984) Phanerozoic Earth History of Australia. Oxford Geological Science Series 2. Clarendon Press, Oxford.

Veevers, J.J. (2000) Antarctic Beardmore-Ross and Mirny Provenances saturate Palaeozoic-Mesozoic east Gondwanaland with 0.6-0.5 Ga zircons. In: Billion Year Earth History of Australia and Neighbours in Gondwanaland (Ed. by J.J. Veevers) Gemoc Press, Sydney.

VermeEsch, P. (2004) How many grains are needed for a provenance study?. Earth Planet. Sci. Lett., 224, 441-451.

Walley, A.M., Cook, P.J., Bradshaw, J., Brakel, A.T., KenNARd, J.M., Lindsay, J.F., Nicoll, R.S., Olissof, S., OWEN, M., Shergold, J.H., Totterdell, J.M. \& Young, G.C. (1991) The Palaeozoic palaeogeography of the Amadeus Basin region. Bureau Mineral Resources, Aust. Bull., 236, 155-169.

Walter, M.R. (1980) Late Precambrian in relation to stratigraphy of the southwestern Georgina Basin, Australia: Correlation chart andexplanatory notes. Bureau of Mineral Resources, Australia Report, 214, BMR Microform MF 92.

Walter, M.R. \& Veevers, J.J. (1997) Australian Neoproterozoic palaeogeography, tectonics and supercontinental connections. AGSO 7. Aust. Geol. Geophys., 17, 73-92.

Walter, M.R. \& Veevers, J.J. (2000) Neoproterozoic Australia. In: Billion Year Earth History of Australia and Neighbours in Gondwanaland (Ed. by J.J. Veevers), pp. 131-153. Gemoc Press, Sydney.

Walter, M.R., Veevers, J.J., Calver, C.R. \& Grey, K. (1995) Neoproterozoic stratigraphy of the Centralian Superbasin, Australia. Precamb. Res., 73, 173-195.

WebBy, B.D. (1978) The history of the continental platform shelf margin of Australia. 7. Geol. Soc. Aust., 25, 41-63.

Wells, A.T., Forman, D.J., Ranford, L.C. \& Cook, P.J. (1970) Geology of the Amadeus Basin, central Australia. Bureau Mineral Resources, Aust. Bull., 100, 222pp.

Williams, I.S. (2001) Response of detrital zircon and monazite, and their $\mathrm{U}-\mathrm{Pb}$ isotopic systems, to regional metamorphism 


\section{W. Maidment et al.}

and host-rock partial melting, Cooma Complex, southeastern Australia. Aust. 7. Earth Sci., 48, 557-580.

Williams, I.S. \& Chappell, B.W. (1998) Crustal evolution in southeastern Australia: a zircon viewpoint. In: The Bruce Chappell Symposium. Granites, island arcs, the mantle and ore deposits, Conference Abstracts. Australian Geological Survey Organisation Record, 1998/33, 44.

Williams, I.S. \& Claesson, S. (1987) Isotopic evidence for the provenance and Caledonian metamorphism of high grade paragneisses from the Seve Nappes, Scandinavian Caledonides. Ion microprobe zircon $\mathrm{U}-\mathrm{Th}-\mathrm{Pb}$. Contrib. Mineral. Petrol., 97, 205-217.

Williams, I.S., Goodge, J., Myrow, P., Burke, K. \& Kraus, J. (2002) Large scale sediment dispersal associated with the late Neoproterozoic assembly of Gondwana. Geol. Soc. Aust., Abstr, 67, 238.

Wingate, M.T.D., Campbell, I., Compston, W. \& GIBSON, G.M. (1998) Ion microprobe U-Pb ages for Neoproterozoic basaltic magmatism in south-central Australia and implications for the breakup of Rodinia. Precamb. Res., 87, $135-159$.

Wingate, M.T.D. \& Giddings, J.W. (2000) Age and palaeomagnetism of the Mundine Well dyke swarm, Western Australia: implications for an Australia-Laurentia connection at $755 \mathrm{Ma}$. Precamb. Res., 100, 355-357.
Wyborn, L., Hazell, M., Page, R., Idnurm, M. \& Sun, S. (1998) A newly discovered major Proterozoic granite-alteration system in the Mount Webb region, central Australia, and implications for $\mathrm{Cu}-\mathrm{Au}$ mineralisation: AGSO Res. Nemsletter, 28, 1-6.

Young, G.C. (1996) Devonian (Chart 4). In: An Australian Phanerozoic Timescale (Ed. by G.C. Young \& J.R. Laurie), pp 96-109. Oxford University Press, Melbourne.

ZhaO, J.X. \& McCulloch, M.T. (1993) Sm-Nd mineral isochron ages of Late Proterozoic dyke swarms in Australia: evidence for two distinctive events of mafic magmatism and extension. Chem. Geol., 109, 341-354.

Zhao, J.X., McCulloch, M.T. \& Bennett, V.C. (1992) Sm-Nd and $\mathrm{U}-\mathrm{Pb}$ zircon isotopic constraints on the provenance of sediments from the Amadeus Basin, central Australia: evidence for REE fractionation. Geochim. Cosmochim. Acta, 56, 921-940.

Zhao, J.X., McCulloch, M.T. \& Korsch, R.J. (1994) Characterisation of a plume-related $\sim 800 \mathrm{Ma}$ magmatic event and its implications for basin formation in central-southern Australia. Earth Planet. Sci. Lett., 121, 349-367.

Manuscript received 1 fuly 2006; Manuscript accepted 17 April 2007. 